\title{
Urban segregation and infrastructure in Latin America: A neighborhood typology for Bariloche, Argentina
}

\author{
Andrés Niembro $^{\mathrm{a}, *}$, Tomás Guevara ${ }^{\mathrm{a}, \mathrm{b}}$, Eugenia Cavanagh ${ }^{\mathrm{a}, \mathrm{b}}$ \\ ${ }^{\text {a }}$ Universidad Nacional de Río Negro. Center for Interdisciplinary Studies on Territory, Economy and Society (CIETES), 265 Mitre Street, Office 4 A, San Carlos de \\ Bariloche, CPI 8400, Argentina \\ ${ }^{\mathrm{b}}$ National Council of Scientific and Technical Research (CONICET), Argentina
}

\section{A R T I C L E I N F O}

\section{Keywords:}

Neighborhood classification

Socioeconomic segregation

Urban infrastructure

Cluster analysis

Latin American cities

\begin{abstract}
A B S T R A C T
The problem of urban segregation has been extensively studied among developed and developing countries. However, in Latin America this phenomenon presents some particularities, such as the role of access to urban infrastructure. Based on data from the latest population census and multivariate analysis techniques, we provide a neighborhood typology for Bariloche, Argentina, which, among other things, enables us to reveal a complex relationship between the socioeconomic level of the population, its residential location, and infrastructure availability. Unlike previous research on Latin American cities, in this case the lowest correlation between these issues seems to indicate that, although urban infrastructure and equipment are important to address urban segregation, public policies should not be limited to only such dimensions.
\end{abstract}

\section{Introduction}

The discussion about urban segregation goes back to the origins of urban studies, revealing a historical concern about how the different socioeconomic classes have been located within the city (Castells, 1977; Ellis, Wright, Holloway, \& Fiorio, 2018). Although this is a long-standing problem in developed countries (Wacquant, 1993), in the last few decades it has also earned an important place in the research on Latin American cities (Kaztman \& Retamoso, 2005, 2007; Roberts \& Wilson, 2009; Ruiz-Rivera \& van Lindert, 2016; Smets \& Salman, 2016) and the evidence shows that this phenomenon presents some particular characteristics in the region (García-Ayllón, 2016).

The socioeconomic and housing inequalities reflected in urban segregation processes have raised the interest of a great variety of authors who have generally sought to analyze and classify different spatial units within the cities, such as neighborhoods or wards, through multivariate analysis techniques. The definition of this kind of typologies has been a frequent objective throughout urban studies in developed countries (Chow, 1998; Delmelle, 2016; Mikelbank, 2004; Reibel \& Regelson, 2007; Wei \& Knox, 2014), as well as in some Latin American cities (Burgos, Koifman, Montaño Espinoza, \& Atria Curi, 2011; Link, Valenzuela, \& Fuentes, 2015; Marmolejo-Duarte \& Batista-Dória de Souza, 2011; Mateos \& Aguilar, 2013) and, particularly, in Argentina (Di
Virgilio, Marcos, and Mera, 2016; Marcos, Mera, and Di Virgilio, 2015; Molinatti, 2013; Sánchez, Sassone, \& Matossian, 2007). Another close field of research in Argentina has been the analysis of regional and territorial inequalities in quality of life (Celemín \& Velázquez, 2017; Velázquez, 2016; Velázquez \& Celemín, 2019; 2020), a topic that has been also studied in the case of Bariloche (Abaleron, 2009; 2016).

Within this framework and based on data from the 2010 population census, we aim to conduct a classification exercise of the neighborhoods of San Carlos de Bariloche city, a case that presents several particularities in advance. Located in Argentine North Patagonia, Bariloche is a recognized tourist destination, both at a national and international level (Vejsbjerg, Núñez, \& Matossian, 2014), but also an intermediate city with regional relevance, since it functions as a political, administrative, and services hub. All this has led to sustained population growth during the past twenty years, becoming the most populated city in Río Negro Province and the third in Argentine Patagonia. However, the accelerated and disordered urban and demographic growth, combined with insufficient or wrong planning policies -which were many times subordinated to particular economic interests-, have implied diverse problems in Bariloche. As we will see later, this is demonstrated, for example, in the provision of urban services and infrastructure, in the territorial distribution of the population, and in the unequal social and housing conditions -in line with some of the Latin American pathologies

\footnotetext{
* Corresponding author.

E-mail addresses: aniembro@unrn.edu.ar (A. Niembro), tguevara@unrn.edu.ar (T. Guevara), ecavanagh@unrn.edu.ar (E. Cavanagh).
} 
highlighted by García-Ayllón (2016)-.

In this sense, the methodology and the exercise proposed in this paper, like in some of the aforementioned studies, seek to provide a multidimensional perspective on the nature of urban segregation processes, instead of focussing on only one or a few dimensions of analysis, like some of the most traditional -even contemporary-approaches or segregation indexes. As Yao, Wong, Bailey, and Minton (2018) state, quantitative studies of segregation are powerful tools for summarizing the relationship between population and space, but sometimes they can lead to over-simplification and over-reduction. Instead, this paper tries to offer more complex results and discussions, particularly, leaving aside binary or dualist positions on these phenomena. In the case of Bariloche but also of other cities, especially tourist ones, it is common to find expressions about urban segregation that are limited to contrasting two realities, the tourist and elite city versus the marginal or popular city, in a north-south or center-periphery analogy (Baños Francia, 2012; González-Pérez, 2013). We will see that there are other realities beyond these two stereotypes, as well as that these two cities hide heterogeneous realities within them.

On the other hand, based on this multidimensional approach, we will also see that the link between socioeconomic level and access to urban infrastructure can be much more complex than the one that supposes a direct and positive relationship between these dimensions. In other words, the fact that higher socioeconomic classes usually live in neighborhoods with better urban infrastructure, and vice versa, is an aspect that will be partially questioned in the case of Bariloche, and that should be considered in the study of other Latin American cities, particularly tourist cities.

After this introduction, the theoretical and empirical backgrounds are briefly revised. Then, we offer a brief overview of the study area and describe the methodology and data used. In the next section, the results are analyzed, beginning with the determination of the number of clusters and ending with their characterization and definition of a neighborhood typology. Finally, we conclude with some discussions in light of previous evidence on Latin American cities.

\section{Theoretical and empirical background}

From the origins of the reflections about the capitalist city, authors like Engels and Booth revealed the inherent inequalities in the way that the different social classes were located within the city. This discussion was resumed in the first decades of the 20th century, with the analysis of urban segregation in the context of the fast industrialization process in the USA (Park, Burgess, \& McKenzie, 1925; Wirth, 1938).

More recently and in the context of globalization, several authors (Dear, 2002; Janoschka, 2002; Janoschka \& Sequera, 2016; Soja, 2000) highlighted the growing heterogeneity within the cities, based on a set of complex and related phenomena such as socioeconomic inequalities, residential segregation, social unrest, delinquency, among others (De Mattos, 2002). Within this framework, numerous authors sought to analyze the differences between neighborhoods through empirical typologies, based on socioeconomic, housing, and demographic variables (Ellis et al., 2018; Mikelbank, 2011; Reibel \& Regelson, 2007; Vicino, Hanlon, \& Short, 2011).

In line with the aim of multivariate analysis techniques -especially, of cluster analysis- and apart from the extensive discussions about the ways of measuring and quantifying segregation (Smets \& Salman, 2016), there is a rather simple definition of urban segregation behind these typologies. Above all, the objective is to identify spatial units that are relatively homogeneous inwards and heterogeneous outwards, which is the approach we also adopt here. According to Sabatini, Cáceres, and Cerda (2001), segregation has three main dimensions: i) the tendency of a group with similar socioeconomic characteristics to concentrate in some areas, ii) the conformation of socially homogeneous areas, and iii) the subjective perception that people have about the objective dimensions. Therefore, in this paper we especially deal with the objective dimensions of this phenomenon.

In the case of Latin America, we can find some segregation studies in the 1970s and 1980s (Rodríguez, Riofrío, \& Welsh, 1973; Scarpaci, Infante, \& Caete, 1988), although the discussion in these decades was mostly focused on the development models of the region and the particular problems of dependence and marginality (Nun, 1969; Quijano, 1972). On the other hand, some authors analyzed the segregation of the native population as a result of the Spanish and Portuguese colonial domination (Sánchez Molina, 2002; Wilde, 1999). From the 1990s onwards, the discussion about urban segregation has increased because of the urban transformations under the neoliberal policies of Washington Consensus (Calderón, 1999; Telles, 1995). For example, Kaztman and Retamoso (2005, 2007) reveal some negative consequences of the segregated environments in Latin American cities in terms of intergenerational reproduction of poverty. ${ }^{1}$ Brain, Cubillos, and Sabatini (2007) state that segregation is a more critical problem in Latin America than it was thought some years ago, since it promotes the social disintegration of popular neighborhoods, with the consequent expansion of problems like drug dealing, crime, school drop-outs, or chronic unemployment. In general, this is close to what is known as neighborhood effects in urban studies, which implies that the structure of opportunities of the individuals is directly and indirectly conditioned by the characteristics of the neighborhood where they live (Sampson, Morenoff, \& Gannon-Rowley, 2002; Sharkey \& Faber, 2014; Wu, He, \& Webster, 2010).

On the other hand, several quantitative studies of segregation in Latin American cities usually employ segregation indexes, such as Duncan's Dissimilarity Index or Massey's Isolation Index (Krüger, 2019; Murillo, Duk, \& Martínez Garrido, 2018). Instead, Rodríguez and Arriagada (2004) postulate that such methods are not suitable for socioeconomic segregation and propose the Residential Segregation Index.

Unlike in Europe or the USA, where segregation studies usually focus on racial segregation (Massey \& Denton, 1993), access to urban infrastructure and services are key issues in the development and analysis of segregation in Latin America (Griffin \& Ford, 1980), much more than the age of the housing stock. This is related to some particularities of urbanization processes in the region and the rise of urban informality. Likewise, the issue of the access to different infrastructures is seen with clarity in several studies on Latin American cities (Burgos et al., 2011; García-Ayllón, 2016; Marmolejo-Duarte \& Batista-Dória de Souza, 2011; Marmolejo-Duarte, Fitch-Osuna, \& Batista-Dória de Souza, 2012; Roy, Bernal, \& Lees, 2020; Vásquez, Peña, \& Cardona, 2008). In most of these cases, it is found that higher socioeconomic classes tend to live in neighborhoods with better access to urban infrastructure, and vice versa.

Currently, two opposite phenomena deepen urban segregation. On the one hand, the large social housing complexes or the informal settlements, and on the other hand, the gated communities. These transformations are changing the traditional patterns of residential segregation, promoting a more fragmented urban structure (Borsdorf, Hildalgo, \& Vidal-Koppmann, 2016; Janoschka, 2002; Janoschka \& Salinas Arreortua, 2017; Janoschka \& Sequera, 2016). Nevertheless, in the middle of these extreme ways of insertion within the city, there are multiple heterogeneities between the open neighborhoods. Indeed, far from the dualization of urban structure, several authors find diffuse and discontinuous urban patterns when analyzing or classifying the neighborhoods of different cities in developing countries (Patel, Koizumi, \& Crooks, 2014; Patel, Shah, \& Beauregard, 2020; Weeks, Hill, Stow, Getis, \& Fugate, 2007) and especially in Latin America (Aguilar \& Mateos, 2011; de Córdova, Fernández-Maldonado, \& del Pozo, 2016; Di Virgilio, M. M., Marcos, \& Mera, 2016; Link et al., 2015; Marcos, Mera, Virgilio,

\footnotetext{
1 There is also evidence of this situation in the context of European cities, as Salom and Fajardo (2017) analyzed, because of the changes associated to migration patterns.
} 
\& M. M, 2015; Mateos \& Aguilar, 2013; Molinatti, 2013; Roy et al., 2020). Meanwhile, the self-production of neighborhoods based on land occupations can be understood not only as a last resource for the vulnerable population, but also as a localization strategy to improve the conditions of integration in the context of growing peripheralization of social housing (Brain, Prieto, \& Sabatini, 2010; Ferguson \& Navarrete, 2003; Janoschka \& Salinas Arreortua, 2017).

\section{Study area, methodology, and data}

\subsection{A brief overview of Bariloche}

As we mentioned, Bariloche is located in Argentine North Patagonia, in the west of Río Negro province, surrounded and crossed by mountains (Cerros), lakes, lagoons, rivers, and streams (Fig. 1). In fact, the landscape has been one of the most significant factors in its consolidation as a recognized tourist destination (Vejsbjerg et al., 2014). However, the most valued natural conditions and tourist attractions are located from the city center to the west, while toward the south and southwest the increasing altitude and distance to Nahuel Huapi Lake produce unfavorable climatic and environmental conditions. This geographic description coincides with the traditional stereotypes of the tourist city and the popular city.

The city area limits with -and is totally surrounded by- the Nahuel Huapi National Park, which was created in 1934 within a nationalist policy of territorial control, especially emphasizing the conformation of a tourist region. Furthermore, the National Parks Administration played a fundamental role in the initial provision of infrastructure, in the urbanization process, in lands policies, and in the expansion of the city area (Vejsbjerg et al., 2014). From that moment, the tourist profile of Bariloche has intertwined with a gradual increase in land prices and the activation of real estate speculation, often with the participation of foreign actors. The landscape and the proximity to lakes and mountains have exercised a differential weight on land prices, not only for housing but also for economic uses, which has an impact on the urban structure and socio-spatial inequalities (Medina, 2017).

In addition to its natural attractions -and the attraction of amenity migrations-, the distance to other urban centers also explains the increasing centrality and population growth of Bariloche. This has also gone hand in hand with a fast urban expansion (Abaleron, 1995; Matossian, 2016), although the city still shows low population densities in big portions of its territory, which is also one of the largest in the country.

Tourism activities have a considerable weight in the production and labor structure and important multiplier effects over the rest of the economy (Kozulj, 2016). However, the local economy faces the typical seasonality of tourism and also the impact of exogenous shocks -such as eruptions of nearby volcanoes, or epidemics like COVID-19-, which usually mean temporary and vulnerable jobs. Labor insertion -or the lack of it- and the quality of jobs not only are common determinants of the socioeconomic level of households but also of residential and housing inequalities (Niembro, Guevara, \& Cavanagh, 2019).

\subsection{Building the database}

As is common in the empirical literature, and in previous studies in Argentina (Di Virgilio et al., 2016; Marcos et al., 2015; Molinatti, 2013; Sánchez, Sassone, \& Matossian, 2007), population censuses are usually the main sources of information. However, one of the difficulties that the censuses present is the geographical unit in which data are collected, especially when we want to analyze within the cities. Traditionally, the most reduced scale for which the information is made public is the census radius, but the definition of its territorial scope is mainly governed by methodological and practical criteria that facilitate data collection, and it does not necessarily coincide with neighborhoods' limits (Di Virgilio et al., 2016; Marcos et al., 2015). This raises an important difference between this paper and the previous study of Sánchez et al. (2007), who defined a first classification of Bariloche's neighborhoods based on data from the 2001 census, which had been previously grouped by neighborhoods by Río Negro's General Directorate of Statistics. This statistical work, which dates from 2005, was carried out based on restricted data corresponding to census blocks. Conversely, nobody has classified the 2010 census by neighborhoods, along with the impossibility to access to data at the level of census blocks.

In this sense, the first contribution of this paper is the grouping by neighborhoods of the 2010 census data, based on the 159 census radii that form the urban area of Bariloche. We prioritized the use of an official and easy access source, the Dynamic Tables of the 2010 Census that were elaborated and published in 2016 by the National Ministry of Energy ${ }^{2}$ for each of the Argentine provinces. In our case, we filtered and kept only the radii corresponding to Bariloche. Then, through a cartographic work that consisted in checking, overlaying, and contrasting the layers of Bariloche's neighborhoods and its census radii, we could define 77 original neighborhoods or groups of neighborhoods (for more details, see Appendix A).

Working with neighborhoods instead of census radii presents several benefits. On the one hand, it is analytically richer and facilitates a better interpretation of the results, since we can tell a story based on the different neighborhood realities. Moreover, we can make some comparisons with the previous contribution by Sánchez et al. (2007). On the other hand, the neighborhood is the spatial unit in which both the offer of urban policies and the demand for them are traditionally expressed. Local, provincial, and national governments usually direct their policies to attend specific neighborhoods and not census radii -an example was the national Neighborhood Improvement Program, known as PROMEBA, in Spanish. Meanwhile, people know in which neighborhood they live but not in which census radius, and they usually discuss and transmit their problems and needs through the Neighborhood Boards (Juntas Vecinales), civil associations with municipal legal status in Bariloche (Matossian, 2016). Neighborhood Boards not only act as a space of interaction between the neighbors and the local government, but also they reinforce the identity of each neighborhood. Finally, it is worth mentioning that some of the first Neighborhood Boards arose from the need to provide urban services to the neighbors, such as the water network, and infrastructure demands remain as the most common requests to the local government.

Another general characteristic of population censuses in Argentina is the application of two different questionnaires. The basic questionnaire contains, as its name implies, a reduced number of questions, but it is applied to all households and, therefore, this information is available at the level of census radii. Instead, the extended questionnaire, which covers a bigger number of questions (for example, about migration, labor situation, access to health and social security, among other dimensions), is applied only to a sample of the population and, therefore, these data are not available for census radii (Marcos et al., 2015). The information obtained from the extended questionnaire is only published at the level of departments, an intermediate geographical scale between the cities and Argentine provinces, which can cover different cities and dispersed rural villages. For example, the department also called Bariloche includes the city (of Bariloche) as a whole but also the city of El Bolsón and different rural settlements.

Despite these limitations of population censuses, the variables collected by the basic questionnaire allow us to cover several socioeconomic and housing dimensions, in line with indicators traditionally used in the empirical literature (Burgos et al., 2011; García-Ayllón, 2016; Marcos et al., 2015; Marmolejo-Duarte \& Batista-Dória de Souza, 2011; Mateos \& Aguilar, 2013; Molinatti, 2013; Roy et al., 2020; Zhou, $\mathrm{Xu}$, Radke, \& $\mathrm{Mu}, 2004)$. As can be seen in Table 1 , variables are

\footnotetext{
${ }^{2}$ Currently, Secretariat of Energy, under the National Ministry of Production.
} 


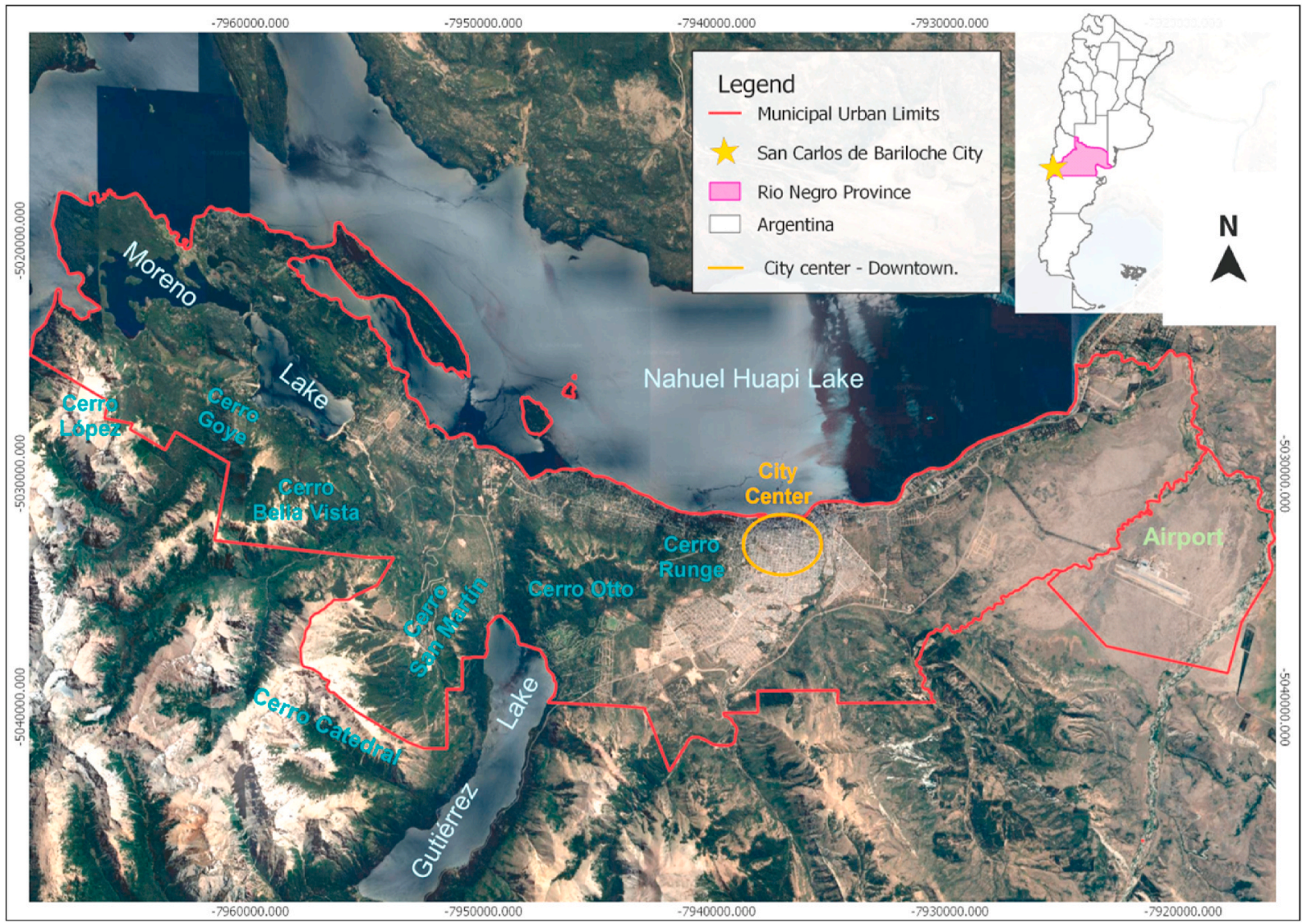

Fig. 1. Localization and geographical characteristics of Bariloche.

Source: Own elaboration based on Google Satellite Image - SRC: EPSG: 3857 - WGS 84 - Pseudo Mercator.

Table 1

Variables description (percentage of total neighborhood households).

\begin{tabular}{|c|c|c|c|c|}
\hline & Mean & $\begin{array}{l}\text { Standard } \\
\text { deviation }\end{array}$ & Minimum & Maximum \\
\hline \multicolumn{5}{|l|}{ UBN } \\
\hline Absence of UBN & 90.1 & 11.5 & 46.7 & 100 \\
\hline \multicolumn{5}{|l|}{ Infrastructure } \\
\hline Access to gas network & 85.6 & 20.2 & 21.2 & 100 \\
\hline Access to sewage network & 53.0 & 40.6 & 0 & 100 \\
\hline Access to water network & 89.7 & 21.2 & 12.4 & 100 \\
\hline \multicolumn{5}{|l|}{ Land tenure regime } \\
\hline Owner of the house and land & 60.7 & 13.4 & 2.5 & 85.0 \\
\hline Tenant & 20.0 & 13.4 & 0.5 & 55.0 \\
\hline $\begin{array}{l}\text { Other forms of land tenure (e.g. } \\
\text { occupation, loan, owner of } \\
\text { the house but not the land) }\end{array}$ & 19.2 & 11.7 & 4.3 & 71.8 \\
\hline \multicolumn{5}{|l|}{ Housing characteristics } \\
\hline Bathroom inside the house & 97.0 & 3.9 & 82.7 & 100 \\
\hline Water pipe inside the house & 94.6 & 8.0 & 59.2 & 100 \\
\hline $\begin{array}{l}\text { Less than two people per room } \\
\text { (no overcrowding) }\end{array}$ & 84.7 & 12.0 & 40.8 & 98.8 \\
\hline \multicolumn{5}{|l|}{ Goods possession } \\
\hline Refrigerator & 95.2 & 5.2 & 75.1 & 100 \\
\hline Computer & 62.4 & 17.4 & 11.4 & 92.0 \\
\hline Fixed-line phone & 59.7 & 18.1 & 12.5 & 86.4 \\
\hline \multicolumn{5}{|c|}{ Education of the head of household } \\
\hline Complete primary school & 88.4 & 9.6 & 59.8 & 100 \\
\hline Complete secondary school & 51.3 & 24.6 & 7.1 & 89.8 \\
\hline $\begin{array}{l}\text { Complete or incomplete higher } \\
\text { education }\end{array}$ & 30.6 & 22.0 & 1.6 & 73.2 \\
\hline
\end{tabular}

Source: Own elaboration. organized in different analysis axes, as in Sánchez et al. (2007): unsatisfied basic needs (UBN), ${ }^{3}$ infrastructure, land tenure regime, housing characteristics, goods possession -a proxy of purchasing power-, and education of the head of household. ${ }^{4}$ To make a clearer and easier interpretation of the results, variables are expressed in a positive sense -e.g. absence of UBN and access to infrastructure or goods-, except for the land tenure regime, where three alternative types are presented, without a previous value judgment. Table 1 also shows that there are considerable levels of variability in most of the indicators, which gives us a first sign of the heterogeneities among Bariloche's neighborhoods. As we will discuss later, the two extreme values highlighted in bold, regarding the land tenure regime, correspond to a very particular neighborhood that, after cluster analysis, will be identified as a unique

\footnotetext{
${ }^{3}$ UBN is a widely used method to account for situations of structural poverty in Latin America, instead of traditional measures of income poverty. In Argentina, households with UBN are those that meet at least one of the following conditions: overcrowding (more than three people per room), inconvenient housing (rented room, precarious housing, or another type), sanitary conditions (not having any kind of toilet), school attendance (presence of a school-age child not attending school), subsistence capacity (four or more people per occupied member and the head of household has not completed third grade of primary school). In contrast, households without UBN are those that do not meet any of these conditions.

${ }^{4}$ Given the dimensions covered by the UBN indicator, a certain degree of relationship with other analysis axes and variables could be presupposed beforehand. However, both the evidence from previous studies (Marcos et al., 2015; Rodríguez, 2001; Rodríguez \& Arriagada, 2004; -Sánchez et al. (2007)) and our results show that this is not necessarily the case. We will see that several clusters have similar levels of UBN but different values in the other dimensions.
} 
case.

\subsection{Multivariate analysis methods}

The methodology adopted here is consistent with the multivariate analysis techniques generally used in the empirical literature, especially the combination of principal component analysis (PCA) and cluster analysis (Chow, 1998; Hanlon, 2009; Manaugh, Miranda-Moreno, \& El-Geneidy, 2010; Owens, 2012; Song \& Knaap, 2007; Vicino et al., 2011). PCA can help us to convert a set of correlated variables in a lower number of uncorrelated factors (Hair, Black, Babin, \& Anderson, 2010; Johnson \& Wichern, 2008). Therefore, factorial analysis is many times a means to an end more than an end in itself (Johnson \& Wichern, 2008), since the results can be used as intermediate inputs for other techniques, such as cluster analysis.

When analyzing the variables included in each axis, we found high levels of correlation between the variables that describe, respectively, housing characteristics, goods possession, and education of the head of household. Accordingly, we resorted to PCA in order to obtain in each case a component that synthesizes the information or variability shared by these correlated indicators. In addition to the analysis of the correlations matrix, the use of PCA is consistent with other statistics criteria that are also satisfied, like Bartlett's test of sphericity, Kaiser-MeyerOlkin measure of sampling adequacy (KMO), and the evaluation of commonalities (Hair et al., 2010). In the three axes, it is appropriate to retain only the first principal component according to the Kaiser criterion, which consists in keeping the components with eigenvalues higher than one. These three new indicators synthesize the information contained in the housing, goods, and education axes, and account for $85 \%$, $89 \%$, and $95 \%$ of the total variance, respectively.

It should be noted that PCA and cluster analysis are sensitive to the use of different measures or scales, so it is initially necessary to standardize the variables (Hair et al., 2010; Johnson \& Wichern, 2008). This is generally performed with $\mathrm{Z}$ scores - i.e. the original variable or score, minus the mean, divided by the standard deviation-, so once standardized they have mean zero and deviation one. On the other hand, the three components previously derived from PCA already have these characteristics. Before proceeding with cluster analysis, we convert into $\mathrm{Z}$ scores the seven indicators corresponding to the axes of UBN, infrastructure, and land tenure regime, and we add to the database the tree principal components that account for housing characteristics, goods possession, and education of the head of household (for a visual inspection of this 10 indicators, see the maps in Appendix B).

In line with our segregation criterion, cluster analysis seeks to maximize the homogeneity among the cases included within each cluster, at the same time that the heterogeneity between clusters is maximized. This allows us to describe the characteristics of each group and, consequently, to define an empirical typology. Within the different alternatives to carry out a cluster analysis, in this paper we resorted to one of the most commonly used hierarchical techniques, the Ward method, together with the proximity measure recommended for this method, the squared Euclidean distance (Hair et al., 2010; Johnson \& Wichern, 2008). It is worth noting that the same technique has been used by several authors (Marcos et al., 2015; Mikelbank, 2004, 2011; Pallas-González, Martínez-Roget, \& Miranda-Torrado, 2000; Sánchez et al., 2007), while others have resorted to alternative hierarchical methods (Aguirre et al., 2013; Bingham, Bowen, \& Kimble, 1997; Link et al., 2015; Salom \& Fajardo, 2017; Webber \& Craig, 1978).

Graphically, hierarchical methods take the form of a tree diagram or, more technically, a dendrogram, which enables us to visually inspect how the clusters are created. In fact, hierarchical techniques usually imply an agglomerative process. In the beginning, each case or object is considered as a cluster in itself. In each stage of the process, the two closest or most similar clusters are joined, until in the end only one cluster is formed. In this sense, the key is to define at what intermediate stage it would be convenient to stop the agglomerative process.
Although this decision may be conditioned by the judgment of each analyst, hierarchical techniques offer some practical criteria -or stopping rules- that can be useful when defining the final number of clusters. Here we followed one of the simplest and most used stopping rules, which consists in analyzing the percentage change in heterogeneity in each stage of the agglomerative process (Hair et al., 2010). When combining step by step different cases and reducing the number of clusters, the heterogeneity inside these clusters -or intra-cluster sum of squared errors, provided by Ward method-tends to increase. If this heterogeneity measure shows a sudden increase when combining two clusters, we can decide not to take that step and keep the previous number of clusters as a final solution.

\section{Results}

\subsection{Determination of the number of clusters}

As can be seen in Fig. 2, a first increase in intra-cluster heterogeneity is produced when passing from 11 groups to 10 , so 11 clusters could be a possible solution. The same criterion could make us consider eight or six clusters as alternative solutions. Although other strong increases are common in the last stages of the agglomeration process, as it happens around three and two clusters, usually these solutions are not analytically interesting, since some cases that are very different from each other have been brought together.

One of the advantages of the dendrogram is the possibility to compare and evaluate the different alternative solutions, analyzing which cases are combined when reducing the number of clusters and whether or not they refer to neighborhoods that should be kept separate. Fig. 3 shows that the differences between 8 and 11 clusters lie in the division of branch B into three subgroups (B1, B2, and B3) and of branch F into two (F1 and F2). As we will see, these more disaggregated clusters present some characteristics that are different from each other, so the solution of 11 clusters is analytically richer and allows us to look inside the traditional stereotypes -or the two faces of the city. The same argument is stressed if we compare with the solution of six clusters, since three of the previous eight groups (C, D, and E) would be integrated into a single cluster, but we will see that they have some marked differences. Statistically, working with 11 clusters is also supported by the analysis of variance (ANOVA), since it is verified that the means of each variable are significantly different between the 11 clusters (Table 2). Finally, although someone could consider 11 clusters as a numerous solution, it is worth noting that, based on data from the 2001 census, Sánchez et al. (2007) defined 16 clusters. This is also a reflection of the marked heterogeneities between Bariloche's neighborhoods, as well as of the greater simplicity and richness of our results.

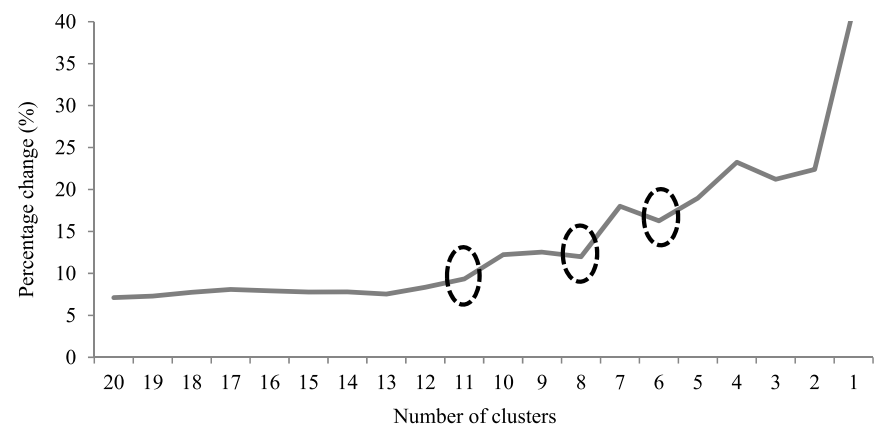

Fig. 2. Percentage change in heterogeneity (intra-cluster sum of squared errors).

Source: Own elaboration. 


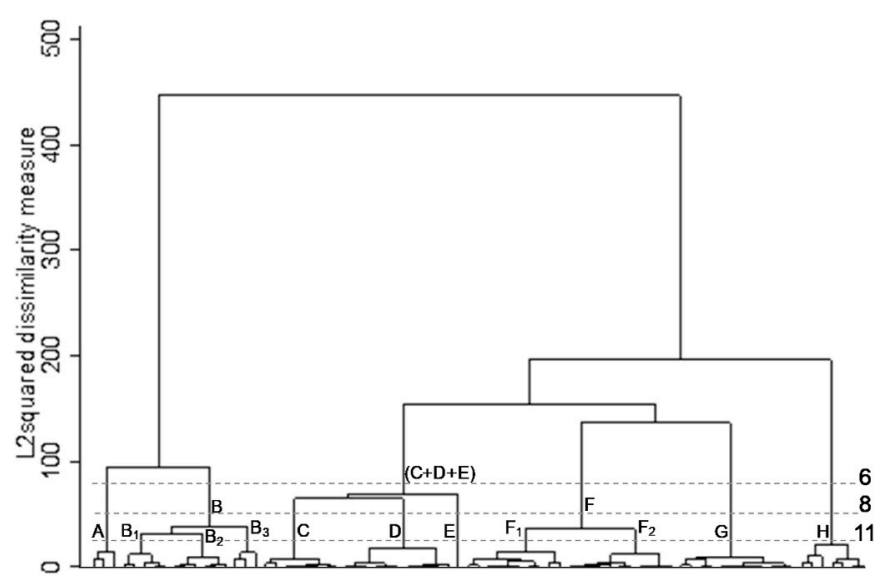

Fig. 3. Hierarchical clustering dendrogram.

Source: Own elaboration.

Table 2

Analysis of variance (ANOVA).

\begin{tabular}{lllll}
\hline & $\begin{array}{l}\text { Sum of } \\
\text { squares }\end{array}$ & $\begin{array}{l}\text { Degrees of } \\
\text { freedom }\end{array}$ & $\begin{array}{l}\text { Mean of } \\
\text { squares }\end{array}$ & $\mathrm{F}$ \\
\hline UBN (absence) & 68.285 & 10 & 6.829 & $58.412^{* * *}$ \\
Water network & 68.858 & 10 & 6.886 & $63.630^{* * *}$ \\
$\begin{array}{l}\text { Sewage } \\
\text { network }\end{array}$ & 65.102 & 10 & 6.510 & $39.425^{* * *}$ \\
$\quad$ Gas network & 61.419 & 10 & & \\
Housing & 64.998 & 10 & 6.142 & $27.799 * * *$ \\
Goods & 65.554 & 10 & 6.500 & $38.988^{* * *}$ \\
Education & 66.692 & 10 & 6.555 & $41.419^{* * *}$ \\
Owner & 57.777 & 10 & 6.669 & $47.289^{* * *}$ \\
Tenant & 64.251 & 10 & 5.778 & $20.925^{* * *}$ \\
Other land & 49.903 & 10 & 6.425 & $36.090^{* * *}$ \\
$\quad$ tenure & & & 4.990 & $12.620^{* * *}$ \\
\hline
\end{tabular}

Significance level: *p $<0,05 ;{ }^{* *} \mathrm{p}<0,01 ; * * * \mathrm{p}<0,001$.

Source: Own elaboration.

\subsection{Definition of a neighborhood typology}

The characteristics of these types of neighborhoods in Bariloche can be analyzed in Table 3, which shows the average of each variable for the 11 clusters. Based on the standardization process, the values respond to the following question: How many standard deviations below or above the mean of all Bariloche's neighborhoods is each cluster average? Given that all the socioeconomic and housing variables -from UBN to
Education in Table 3- are expressed in a positive sense, negative values account for situations of scarcity or vulnerability. To make it even more visual, a scale of reds and greens is used to distinguish between disadvantageous and favorable situations. The color scale responds to the following criteria: dark when the cluster average is higher or lower than \pm 1 , intermediate for values between \pm 0.5 and \pm 0.99 , and pale between \pm 0.49 and 0 . The same coloring is applied to the different variables that characterize the land tenure regime. Since there is not a previous value judgment about these alternative situations, the colors do not imply favorable or unfavorable cases in advance, but they only show the distance between the cluster average and the general mean.

The following map (Fig. 4) allows us to visualize the geographical location of the neighborhoods that make up the 11 clusters. Although this dimension has not been part of cluster analysis -since it is not a variable defined by the census-, we consider the location when interpreting the results obtained, schematically distinguishing whether they are central, suburban, or periurban neighborhoods. In other words, we cross the information in Table 3 with this map to characterize the different types of neighborhoods in Bariloche and to derive an empirical typology.

A first particular case that is isolated by cluster analysis is cluster E, which covers only one unit of analysis, formed by the Military neighborhood and the Bariloche Atomic Center. The outstanding characteristic of this agglomeration is that the inhabitants -who, on average, have high education and purchasing levels- are occupants for working reasons of state homes that belong to different public agencies and have good housing conditions and access to infrastructure. The other side of this particular type of occupation is the practically null percentage of owners. This case had already been identified as a cluster in itself by Sánchez et al. (2007), based on data from the 2001 census. However, while Sánchez et al. (2007) got six clusters composed of a single neighborhood, cluster $\mathrm{E}$ is the only one here, which allows us to develop an analytically richer neighborhood typology.

If we lay aside cluster E, since it represents a very specific and isolated case, 10 types of neighborhoods can be identified in Bariloche. For a matter of simplicity in ordering and discussing the results, some of these 10 clusters will appear under a general category that follows the logic of the main branches of the dendrogram. Moreover, we will see that the first categories correspond to the (center-periphery) stereotypes that this article seeks to break, showing the heterogeneity within them. Meanwhile, the remaining clusters will show other particular realities beyond these traditional stereotypes. Although the following typology naturally responds to the case of Bariloche, we will mention other studies that suggest that some aspects are also shared with other Latin American cities. Lastly, despite some differences in the methodology and data, we will also highlight some clusters that are similar to the ones

Table 3

Cluster averages in each variable.

\begin{tabular}{|c|c|c|c|c|c|c|c|c|c|c|}
\hline \multirow[b]{2}{*}{ Cluster } & \multicolumn{7}{|c|}{ Socioeconomic and housing variables } & \multicolumn{3}{|c|}{ Land tenure regime } \\
\hline & $\begin{array}{c}\mathrm{UBN} \\
\text { (absence }\end{array}$ & Water & Sewage & Gas & Housing & Goods & $\begin{array}{l}\text { Educa- } \\
\text { tion }\end{array}$ & Owner & Tenant & Other \\
\hline A & -3.52 & 0.26 & -0.79 & -2.62 & -2.97 & -3.05 & -1.64 & 0.36 & -1.36 & 1.13 \\
\hline B1 & -1.46 & 0.45 & 0.41 & -0.33 & -1.78 & -1.24 & -1.42 & 0.36 & -1.07 & 0.81 \\
\hline $\mathrm{B} 2$ & -0.52 & 0.43 & -1.09 & -0.24 & -0.65 & -0.50 & -0.89 & 0.41 & -0.65 & 0.27 \\
\hline B3 & -0.64 & -0.75 & -1.02 & -2.47 & -1.15 & -1.48 & -0.75 & -0.21 & -0.91 & 1.28 \\
\hline $\mathrm{C}$ & -0.53 & 0.47 & 0.77 & 0.17 & -0.17 & -0.30 & -0.61 & -0.66 & 0.23 & 0.49 \\
\hline $\mathrm{D}$ & 0.47 & 0.48 & 1.02 & 0.61 & 0.49 & 0.38 & 0.54 & -1.25 & 1.70 & -0.50 \\
\hline E & 0.80 & 0.25 & 0.66 & 0.44 & 0.91 & 1.19 & 1.26 & -4.34 & 0.43 & 4.49 \\
\hline F1 & 0.45 & -0.15 & -1.01 & 0.18 & 0.38 & 0.56 & 0.75 & 0.39 & -0.14 & -0.29 \\
\hline F2 & 0.75 & 0.28 & -0.19 & 0.64 & 0.85 & 1.15 & 1.31 & 0.08 & 0.77 & -0.97 \\
\hline $\mathrm{G}$ & 0.53 & 0.47 & 1.07 & 0.66 & 0.48 & 0.20 & -0.76 & 1.10 & -0.84 & -0.30 \\
\hline $\mathrm{H}$ & 0.29 & -2.85 & -1.27 & -0.99 & 0.20 & -0.12 & 0.64 & 0.10 & -0.27 & 0.19 \\
\hline
\end{tabular}

Source: Own elaboration. 


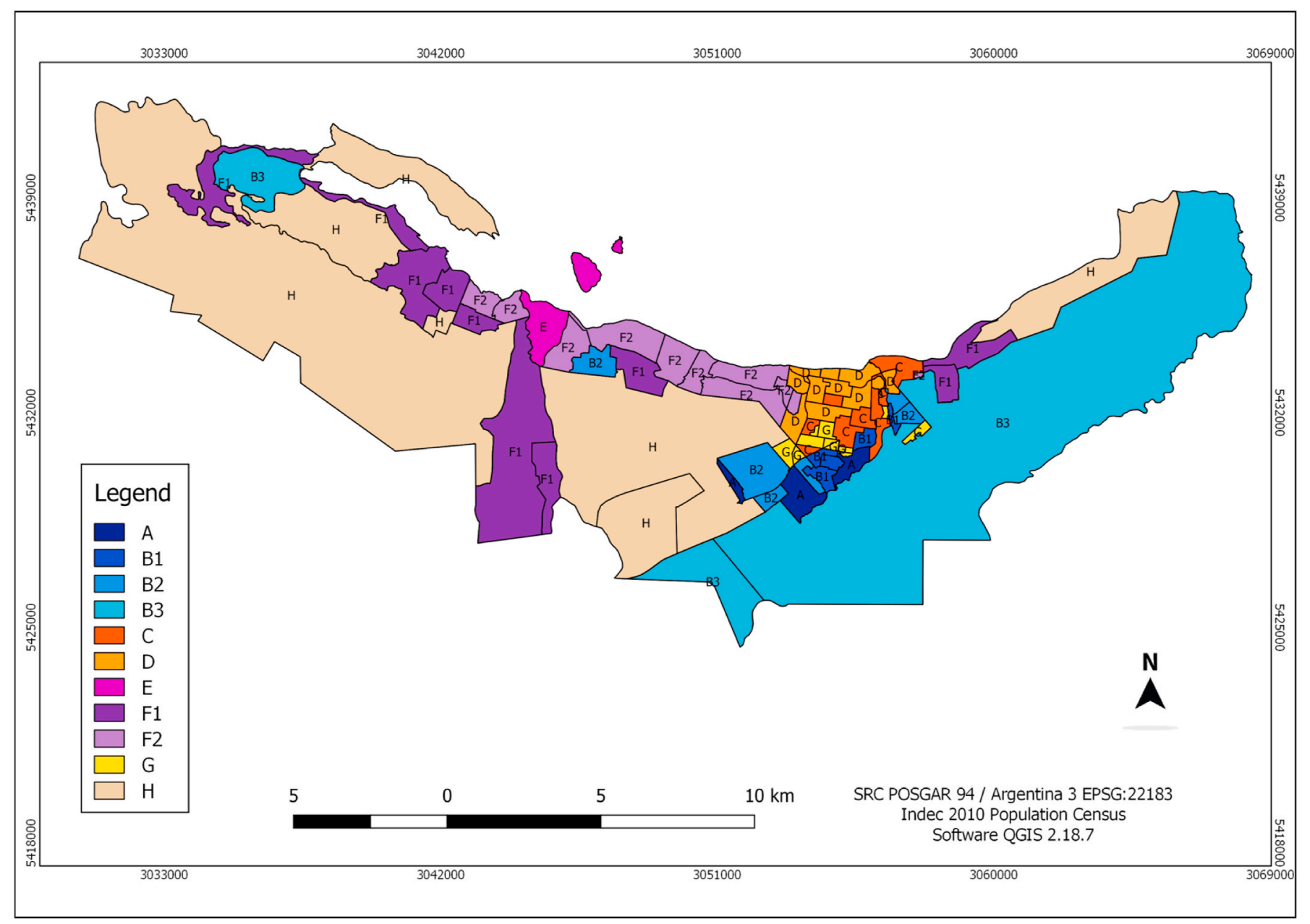

Fig. 4. Map of the different clusters of neighborhoods in Bariloche.

Source: Own elaboration based on the cartography of the National Institute of Statistics and Censuses (INDEC).

identified by Sánchez et al. (2007), based on the 2001 census. This reflects the stability of some socio-spatial inequalities throughout the 2000s.

Suburban popular neighborhoods: A and Bs (B1, B2, B3).

In general, all these neighborhoods are located in suburban areas -or in the margins of the city center-and are popular neighborhoods in the sense that lower-middle and lower classes live there, mainly salaried -formal or informal-, unemployed, or workers of the popular economy. In a simplistic and a bit stereotyped way, these neighborhoods are traditionally called el Alto, because of the altitude of these areas. However, there are some differences between the four groups of neighborhoods identified by cluster analysis, not only in socioeconomic levels but also in the access to infrastructure (López, Cukier, and Sánchez López, 2006; Silveira \& Rodrigues, 2015).

In cluster A we find suburban popular neighborhoods with restrictions in infrastructure and very low socioeconomic level (e.g. Unión, 2 de Abril, Nahuel Hue, Vivero, similar to Sánchez et al., 2007). ${ }^{5}$ They show the worst conditions in terms of UBN, education, goods possession -purchasing power-, and housing characteristics, in addition to reduced access to sewage and gas networks. In general, these are recently formed neighborhoods, mainly by informal occupations of lands, which impacts in their lack of urban consolidation (Enríquez Acosta, 2008; González-Pérez, Remond, Rullan, \& Vives, 2016; Torres \& Momsen, 2005). This group shares some similar characteristics with cluster B3,

\footnotetext{
${ }^{5}$ In Appendix $\mathrm{C}$ we present a complete list of the neighborhoods that form each cluster.
}

which we called peri-urban popular neighborhoods with great restrictions in infrastructure and low socioeconomic level (e.g. Llanquihue, Pilar 1 and 2, peri-urban radius). Along with the reduced purchasing power and irregular land tenure, the remoteness of these neighborhoods also explains the deprivations in terms of urban infrastructure -e.g. a marked lack of water network.

In contrast, clusters B1 and B2 correspond to relatively consolidated popular neighborhoods, based on their greater access to infrastructure and urban services. However, the socioeconomic level of B1 is more like B3, so we talk about suburban relatively consolidated popular neighborhoods with low socioeconomic level (e.g. Arrayanes, Eva Perón, Mutisias, Progreso, similar to Sánchez et al., 2007). Although cluster B2 presents, on average, some limitations in the access to sewage network -in part for being a little bit further from the city center-, we can talk about suburban relatively consolidated popular neighborhoods with better socioeconomic conditions (e.g. Frutillar, Omega, San Francisco 2 and 3, Virgen Misionera). In comparative terms, cluster B2 shows higher values of housing, education, and purchasing power.

Consolidated central neighborhoods: C and D

These neighborhoods are very consolidated in terms of infrastructure and urban services, but they present some socioeconomic and location differences (Baños Francia, 2012; Everitt, Massam, Chávez-Dagostino, Espinosa Sánchez, \& Andrade Romo, 2008; Torres \& Momsen, 2005; Valenzuela Valdivieso \& Coll-Hurtado, 2010). While cluster D includes spatial units in the core of the city center -or downtown-, the neighborhoods in cluster $\mathrm{C}$ are generally located in the first ring around downtown. Cluster D also shows high education and purchasing power 
levels, so we talk about downtown consolidated neighborhoods of upper-middle classes (e.g. downtown radius, Belgrano, Anasagasti, El Mallín). Moreover, in cluster D we find the highest percentages of tenants or renters in the city, due to verticalization and densification processes. On the other hand, there is a smaller proportion of owners living there. Instead, cluster $\mathrm{C}$ includes (macro-) central consolidated neighborhoods of lower-middle classes, with more precarious homes, UBN, and lower education levels (e.g. Lera, San Francisco 1, Ceferino, Nueva Esperanza).

Suburban neighborhoods of upper-middle classes: Fs (F1 and F2).

In search of the landscape, Bariloche city has grown in extension along the Nahuel Huapi Lake, following Bustillo and Pioneros Avenues to the West and Route 237 to the East. That is why the neighborhoods in this expansion axes, particularly the ones to the West, are generically known as los kilómetros -i.e. the kilometers, as a measure of distance to the city center-. This is the preferred location for the middle and upper-middle classes, who live in neighborhoods with relatively good infrastructure and urban services (Celemín, 2012; Everitt et al., 2008; López, Cukier, \& Sánchez, 2006; Torres \& Momsen, 2005; Valenzuela Valdivieso \& Coll-Hurtado, 2010), with the particular exception of the access to sewage network, which is restricted due to the distance to the city center or the lower age of some of these neighborhoods (Silveira \& Rodrigues, 2015). The latter is more evident in cluster F1, which we call suburban relatively consolidated neighborhoods of upper-middle classes (e.g. Lago Moreno, Casa de Piedra, Playa Serena, Los Coihues). On the other hand, these limitations are much more isolated in cluster F2, which not only is closer to the city center but also presents higher levels of education and purchasing power, as well as a higher proportion of tenants -only behind cluster D-. In this case, we talk about suburban consolidated neighborhoods of upper-middle classes (e.g. Cipresales, Las Vertientes, Maitenes, Melipal, Pinares, similar to Sánchez et al., 2007).

Neighborhoods of social housing and infrastructure for lower-middle classes (between the city center and the suburbs): G.

These are neighborhoods where lower-middle and lower classes live, with an also low education level but with very good urban infrastructure conditions -practically the same as cluster D- and the highest proportion of homeowners in the city. These characteristics are mostly explained by the fact of being social housing complexes built by the State (e.g. 40, 84, $112,154,204,218,400$ houses, similar to Sánchez et al., 2007), in many cases several decades ago and in the margins of the city center or near suburban areas (Matossian, 2016), given the higher availability of lands at that moment.

Suburban neighborhoods of middle classes with infrastructure restrictions: $\mathrm{H}$.

In cluster $\mathrm{H}$, we find middle classes -and some upper-middle sectors as well- with a good education level. However, in search of the natural environment, the proximity with the forest or the lake, they live in neighborhoods far from the city center and with some physical barriers in-between, like hills or mountains (e.g. Colonia Suiza, Península, El Trébol, Lago Gutiérrez). For these reasons, some infrastructures and urban services are still scarce (Celemín, 2012; López et al., 2006).

\section{Discussion and conclusions}

Practically from the beginnings of the reflection about the capitalist city, there was a concern for analyzing the location of the different social classes within the city and the level of urban and social segregation they experience. Throughout this paper, we appreciate that Bariloche is a heterogeneous, fragmented, and segregated city. However, the neighborhood typology that we propose transcends traditional stereotypes -the city center, el Alto, or the kilometers- and gives a much more complex perspective. It is clear that this heterogeneity is not limited to a comparison of the clusters, but we could also find differences between the neighborhoods that form each cluster or within the neighborhoods themselves. In this sense, although cluster analysis facilitates a general overview that can be useful for urban planning and management, the study of urban inequalities could be deepened in future research.

Despite these possible limitations, as well as not being able to account for the subjective dimension of segregation -as we do not have data on this issue-, this paper provides a multidimensional and complex perspective on the nature of urban segregation. Many quantitative and segregation indexes that only focus on a few dimensions or variables, usually arrive at binary or dualist results -e.g. center-periphery-. Instead, we show that the traditional two faces of the city hide heterogeneous realities within them, as well as that there are other realities beyond these two simplistic stereotypes. This is an interesting result that naturally responds to the case of Bariloche, but that could also be taken into account in the analysis of other Latin American cities, especially tourist ones.

A remarkable aspect of Bariloche is that urban fragmentation and segregation are not directly associated with the well-studied phenomenon of gated communities, since there are few and exceptional cases of closed or private neighborhoods, but rather with inequalities between open neighborhoods. Another distinctive issue, which also contributes to the discontinuity and dispersion of the urban area, is the physical environment itself and the presence of natural barriers that condition the urbanization patterns. For example, the Cerro Otto -whose radius integrates cluster $\mathrm{H}$ - is a geographic element that blocks the continuous development of the urban structure, separating some upper-middle-class neighborhoods (cluster F2) from the popular neighborhoods toward the South (A and Bs). Obviously, these characteristics impact on urban segregation, or have been even functional to these processes as a way of hiding some portions of the population (Pérez, 2004).

Bariloche presents a disperse and extensive urban area, with fuzzy limits and discontinuous urbanized spots in some places. Some examples are the popular neighborhoods of clusters A, B2, and B3, but also some middle-class neighborhoods, such as clusters F1 and $\mathrm{H}$, each one with their particularities and differences. These last cases -F1 and especially $\mathrm{H}$ - represent a counterexample to the previous Latin American evidence that have usually shown a direct relationship between the access to urban infrastructure and the socioeconomic level of the population. In Bariloche, it seems that some people consider that the availability of natural amenities compensates the lack of certain services, which on the other hand can be obtained from the same physical environment -like water streams- or can be remedied somehow -e.g. through a correct treatment of residential effluents-. Another counterexample, but on the contrary, is cluster $\mathrm{G}$ of social housing complexes built by the State and destined to lower-middle and lower classes. Due to the characteristics of these housing policies of several decades ago and the proximity to the city center, urban infrastructure and services are guaranteed. A similar relationship between relatively good infrastructure and popular classes is seen near the margins of the city center, in clusters C and B1. Consequently, only in the core of the city center and the near uppermiddle-class neighborhoods (groups D and F2), there is a direct link between urban services and favorable socioeconomic conditions.

In turn, some clusters also reflect different stages or models of urban and housing policies. Cluster $\mathrm{G}$ shows this clearly, since it concentrates the social housing complexes typical of past decades, which were mainly the product of the eradication and relocation of precarious settlements (Pérez, 2004). Meanwhile, clusters A and B show, with different degrees of maturation, the evolution of informal urbanization processes from the 1980s onwards, which consist of lands occupations and later policies of housing regularization (Ferguson \& Navarrete, 2003). These policies have sought to keep the population in their settlement place, based on progressively improving their homes, regularizing the housing tenure, and supplying these neighborhoods with community equipment and urban services.

As a corollary, the lack of correlation observed in some Bariloche's neighborhoods between the socioeconomic level of the population and the access to urban services allows us to reflect on the different dimensions of urban segregation and urban policies. In Bariloche -and 
other Latin American tourist cities-, the social valuation of the natural environment not only conditions the direction of urban growth but also tends to complicate the provision of urban infrastructure. This represents a particular challenge for urban planning and management in increasingly diffuse tourist cities.

Beyond urban infrastructure and equipment, which naturally are central aspects of urban integration, it is clear that there are other dimensions linked to socioeconomic integration and a more symbolic component that has to do with the sense of being connected to a community. Urban disintegration, low population densities, long distances, and geographical accidents contribute to the urban problems in Bariloche -and many Latin American tourist cities-. Therefore, it is important to guide the future growth of the city and promote an urban structure more compact and densified, balancing or limiting the market forces that usually tend to urban diffusion. Finally, urban integration may require better and more intelligent forms -and spaces- of urban connectivity. As suggested by Liu et al. (2019), the aggregation of urban functions and services in established or emerging secondary centers, and increasing their functional linkages and connectivity as urban hubs, could be an interesting strategy.

\section{Funding}

This work was supported by the National Agency for Scientific and
Technological Promotion (ANPCYT, Argentina) under the research grant PICT 2015-3020.

\section{CRediT authorship contribution statement}

Andrés Niembro: Conceptualization, Methodology, Software, Validation, Formal analysis, Investigation, Resources, Data curation, Writing - original draft, Writing - review \& editing, Supervision, Project administration. Tomás Guevara: Conceptualization, Investigation, Writing - original draft, Writing - review \& editing, Funding acquisition. Eugenia Cavanagh: Software, Resources, Data curation, Visualization.

\section{Declaration of competing interest}

No potential conflict of interest is reported by the authors.

\section{Acknowledgements}

We are grateful for the collaboration of Marcelo Verbeke in the initial setup of the database. We also thank the valuable comments of Cristina Cravino to a previous version, as well as the suggestions of the anonymous reviewers of the journal. As usual, we are solely responsible for any remaining errors.

\section{Appendix A. Description of conversion from census radii to neighborhoods}

As we mentioned before, the limits of census radii do not necessarily coincide with neighborhoods limits. Nevertheless, in some cases, a radius matches relatively well the limits of a neighborhood (e.g. San Francisco 1, Jardín Botánico) or of a group of adjacent neighborhoods less populated in 2010 (e.g. San Francisco 2 and 3, or the East, which covers Villa Verde, INTA, La Colina, Aldea del Este, and Las Marías). On other occasions, it was necessary to put together two or more radii to approximate the scale of a bigger and more populated neighborhood (e.g. Frutillar, Las Victorias) or, given the changing limits of the radii, to cover an area close to a group of adjacent neighborhoods (e.g. Unión and 2 de Abril, denominated 34 ha, Arrayanes and Eva Perón, or the group that we call Pinares, from Pinar del Lago to Pinar de Festa). Based on the union of census radii, a new cartography (reflected in Fig. 4) was developed, which helps us to incorporate the territorial dimension when describing the clusters.

In all the cases in which the comparison between cartographies indicated the need of joining two or more census radii, we also followed the criterion of ensuring certain homogeneity among them, particularly comparing the percentage of homes with at least one indicator of unsatisfied basic needs (UBN). Furthermore, this criterion was essential to settle some complex cases where the radii did not adjust to the limits of a neighborhood or a group of adjacent neighborhoods and constantly crossed from one neighborhood to another (e.g. in Las Quintas, Nueva Esperanza, Lera, Las Mutisias, and Perito Moreno). In these cases, we identified a core radius for each neighborhood and the remaining radii were distributed combining the geographical criterion and the homogeneity in UBN. On other occasions (e.g. in Lomas de Monteverde), the homogeneity criterion led us to divide the neighborhood into two fractions (North and South), since their respective radii presented different levels of UBN. Finally, it is worth noting that, instead of working with the city center as a unique big area that would integrate more than ten radii, it was divided into smaller subsections, in line with the rest of the identified units. The next table of correspondences (Table A1) shows how the 159 census radii were distributed among the 77 neighborhoods -or groups of neighborhoods- defined, which allows other researchers or policymakers to replicate or improve the work done.

Table A.1Neighborhoods or groups of neighborhoods defined

\begin{tabular}{|c|c|c|}
\hline ID & Neighborhoods & Census radii \\
\hline 10DIC & 10 de Diciembre & 620210903 \\
\hline 112_84V & $112-84$ viv & 620211808 \\
\hline $120 \mathrm{~V}$ & 120 viv. & 620211408 \\
\hline 154_204_218V & 154-204-218 viv & $620211603+11604+11605$ \\
\hline $181 \mathrm{~V}$ & 181 viv & 620211009 \\
\hline 34HAS & Unión-2 de Abril & $620210203+10212$ \\
\hline 3LAGOS_MORENO & 3 Lagos-Lago Moreno & $620210107+10111$ \\
\hline $400 \_40 \mathrm{~V}$ & $400-40$ viv Movitur & $620210207+10208$ \\
\hline 80VCOVI & 80 viv Covitur & 620211412 \\
\hline $96 \_144 \mathrm{~V}$ & Amancay 96-Güemes 144 viv & 620211608 \\
\hline ABED_VURI & Abedules-Vuriloche & 620211701 \\
\hline ALBOR_BV & Alborada-Bella Vista & 620211607 \\
\hline ANASAG & Anasagasti & $620210801+10802+10803+11506+11507$ \\
\hline ANTU170V & Antu Hue 170 viv & 620211011 \\
\hline ARRAY_EVA & Arrayanes-Eva Perón & $620211705+11706$ \\
\hline BELGRANO & Belgrano & $620210311+10312+10313$ \\
\hline BONITA_SIC & Playa Bonita-San Ignacio del Cerro & $620211102+11113$ \\
\hline BOTANICO & Jardín Botánico & 620210907 \\
\hline CAB_MILITAR & Centro Atómico Bariloche-Barrio Militar & 620211101 \\
\hline
\end{tabular}


(continued)

\begin{tabular}{|c|c|c|}
\hline ID & Neighborhoods & Census radii \\
\hline CANTERA_OMEGA & Toma Cantera y parte de Omega (Sur) & 620211710 \\
\hline CASAPIEDRA & Casa de Piedra & $620211205+11206$ \\
\hline CATEDRAL & Villa Catedral & 620211209 \\
\hline CENTRO_NE & Centro-Noreste & $620210306+10307+10308+10309+11503+11504+11505$ \\
\hline CENTRO_NIRE_O & Centro-Ñireco Oeste & $620211804+11805$ \\
\hline CENTRO_NO & Centro-Noroeste & $620210301+10302+10310$ \\
\hline CENTRO_S & Centro-Sur & $6202111502+11508+11509+11511+11512$ \\
\hline CENTRO_SO & Centro-Sudoeste & $620210901+10902+11501+11510$ \\
\hline COIHUES & Los Coihues & $620211207+11208$ \\
\hline COLSUIZA & Colonia Suiza & 620210112 \\
\hline CONDOR_NIRE_NE & Ñireco Noreste-El Cóndor & 620211801 \\
\hline COOP258 & Coop. 258-El Maitén & 620211402 \\
\hline CSOL_CHACRAS & Costa del Sol-Las Chacras & 620211417 \\
\hline CUMBRE & La Cumbre-Alto Jardín & $620210906+10908+10909$ \\
\hline ELFL300V & Elflein 300 viv & 620211606 \\
\hline ESTE & Villa Verde-INTA-La Colina-Aldea del Este-Las Marías & 620211416 \\
\hline FALDEO_RANCHO & Faldeo-Rancho Grande-Ladera Norte & $620211109+11110+11114$ \\
\hline FRUTI & Frutillar & $620210204+10205+10206+10209+10210+10211$ \\
\hline GUTIER_ARELAU & Lago Gutiérrez-Arelauquen & 620210202 \\
\hline JAMAI_COVI & Villa Jamaica-Covibar & 620210110 \\
\hline KM4_5 & Carihue-El Prado-Rayen Mapu (incl. parte de El Faldeo) & $620211301+11302+11310+11311$ \\
\hline LERA & Lera & $620210804+10805+11806+11809$ \\
\hline LEVA266V & Levalle 266 viv & 620211609 \\
\hline LLANQUIH & Llanquihue (y Don Bosco) & 620210102 \\
\hline LLAO_CAMPAN & Llao Llao-Campanario & $620210101+10103$ \\
\hline MAITEN_CIPRES & Maitenes-Cipresales-Runge Superior & $620211304+11305$ \\
\hline MALLIN_FURMAN & Mallín-Furman-Santo Cristo & $620210904+10905+11601+11602$ \\
\hline MARGARIT & Las Margaritas & 620211306 \\
\hline MELIPAL & Melipal & $620211303+11308+11309$ \\
\hline MICROCENTRO & Microcentro & $620210303+10304+10305$ \\
\hline MONTEV_NORTE & Monteverde (Norte) & 620211802 \\
\hline MONTEV_SUR & Monteverde (Sur) & 620211807 \\
\hline MUTI_PM & Las Mutisias-Perito Moreno & $620211005+11006+10810$ \\
\hline NAH_MALV & Nahuel Hue-Malvinas & $620211403+11404+11406+11407$ \\
\hline NMALAL & Nahuel Malal & $620211201+11202$ \\
\hline NVAESPER & Nueva Esperanza & $620210806+10807+10808+10809$ \\
\hline OMEGA & Omega (Norte) & $620211405+11709$ \\
\hline ORIONE_VESCOND & Don Orione-Valle Escondido & 620210105 \\
\hline OTTO_LADERAS & Cerro Otto: Laderas superiores & 620210201 \\
\hline PAJAZ̄UL & Pájaro Azul & $620211203+11204$ \\
\hline PENINS & Península San Pedro & 620210104 \\
\hline PERIURB & Periurbano & 620211418 \\
\hline PEUMA153V & Peumayén 153 viv & 620211703 \\
\hline PILAR & Pilar & 620211401 \\
\hline PINARES & Pinar del Lago-Pehuen-La Cascada-Montelindo-Pinar de Festa & $620211103+11104+11105+11106+11107+11108$ \\
\hline PROGR_ARG & Progreso-Argentino-28 de Abril & $620211702+11707$ \\
\hline QUIMEY & Quimey Hue & 620211708 \\
\hline QUINTAS_CEFE & Las Quintas-San Ceferino-6 Manzanas & $620211001+11002+11003+11004+11007+11008$ \\
\hline SANFRAN1 & San Francisco I & 620211803 \\
\hline SANFRAN2_3 & San Francisco II y III & $620211409+11410$ \\
\hline SANFRAN4 & San Francisco IV-130-40-20 viv & 620211411 \\
\hline SANMA169V & San Martín 169 viv & 620211010 \\
\hline SERENA_JOCK & Playa Serena-Jockey & $620210108+10109$ \\
\hline TREBOL & El Trébol & 620210106 \\
\hline VERTIENT & Las Vertientes & 620211307 \\
\hline VICTORIAS & Las Victorias & $620211413+11414+11415$ \\
\hline VIRGEN & Virgen Misionera & $620211111+11112$ \\
\hline VIVERO & Vivero & 620211704 \\
\hline
\end{tabular}

Appendix B. Maps of the ten indicators employed in cluster analysis ${ }^{6}$

\footnotetext{
${ }^{6}$ The color scale in the maps is the same as in Table 3.
} 

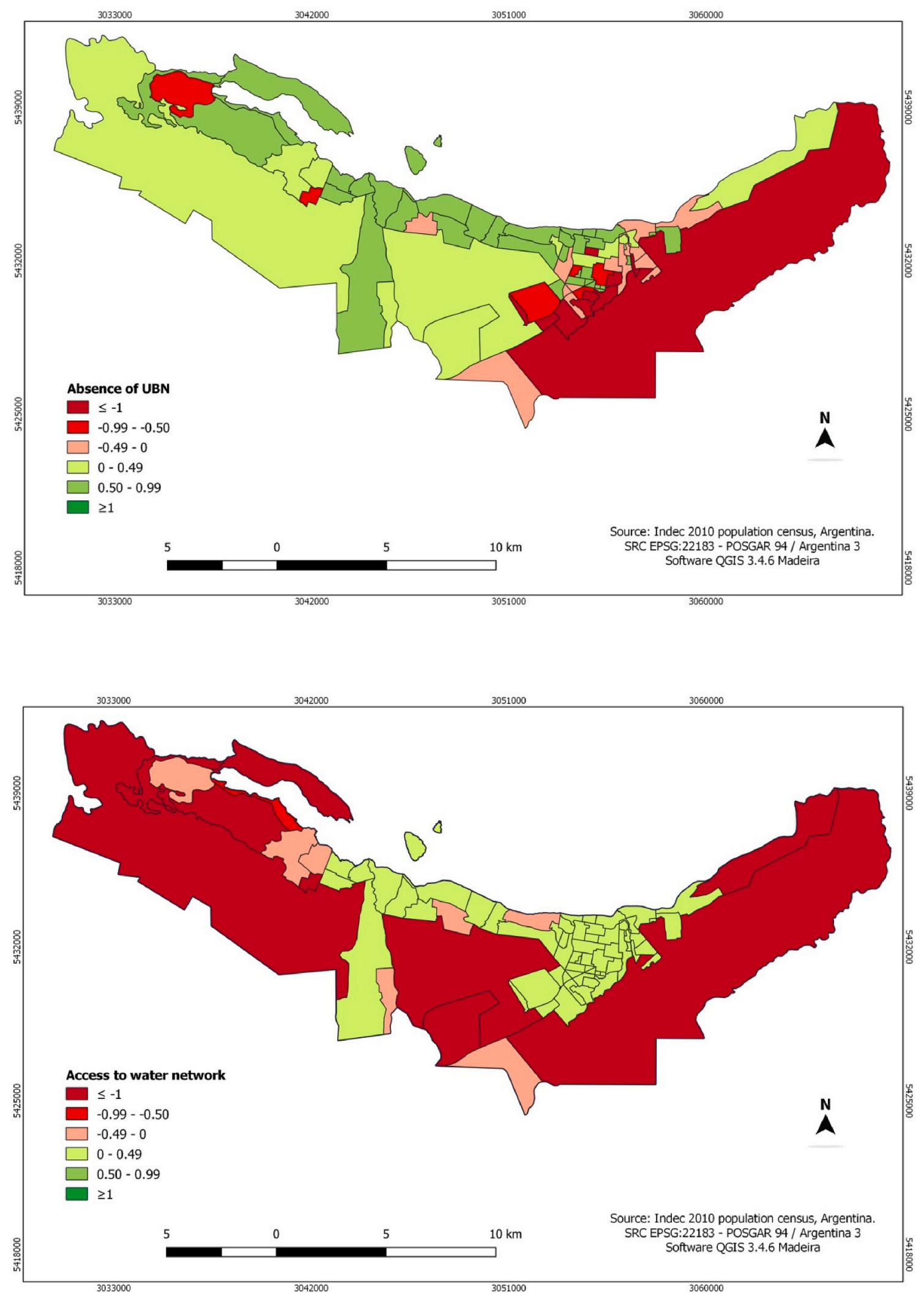

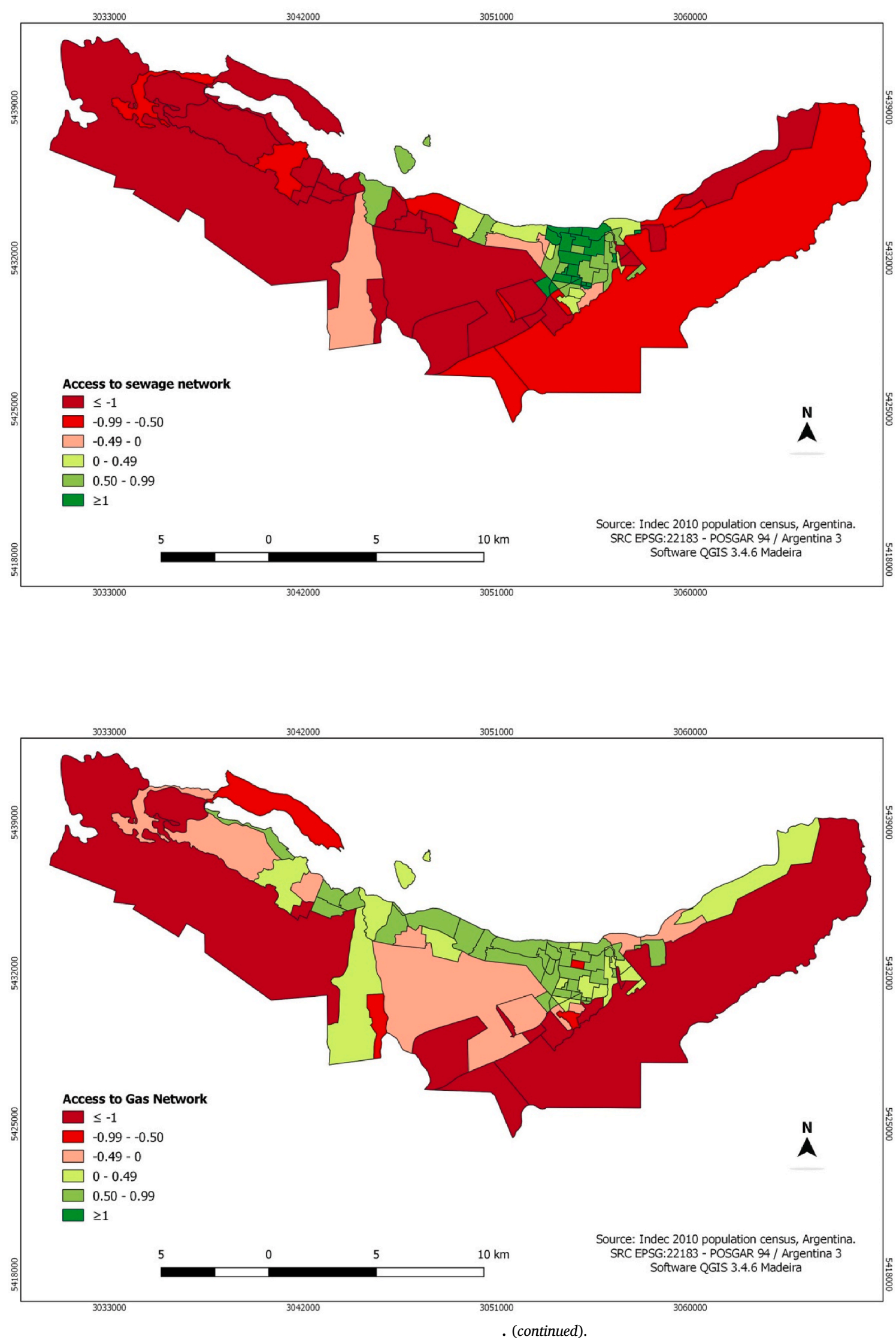

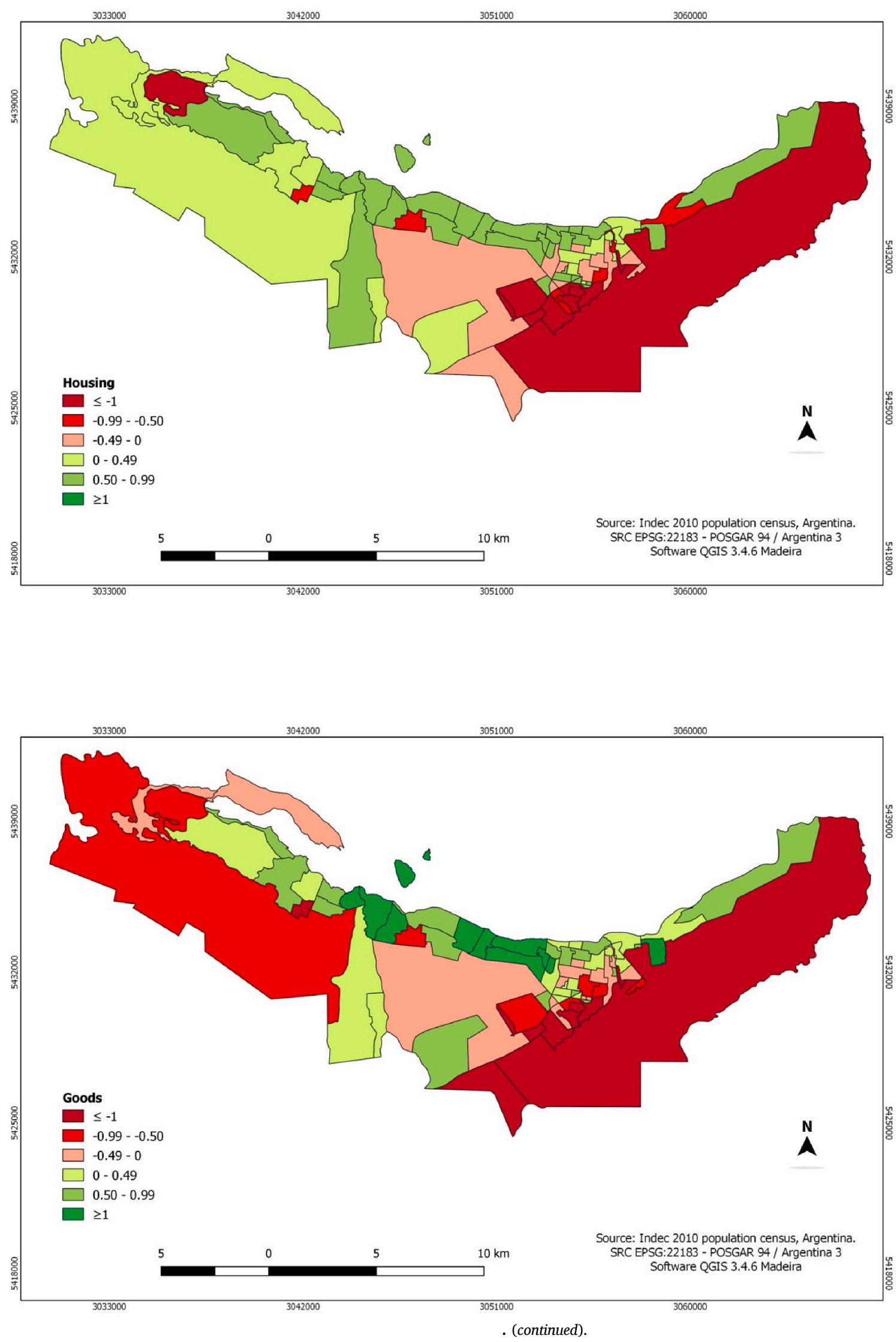

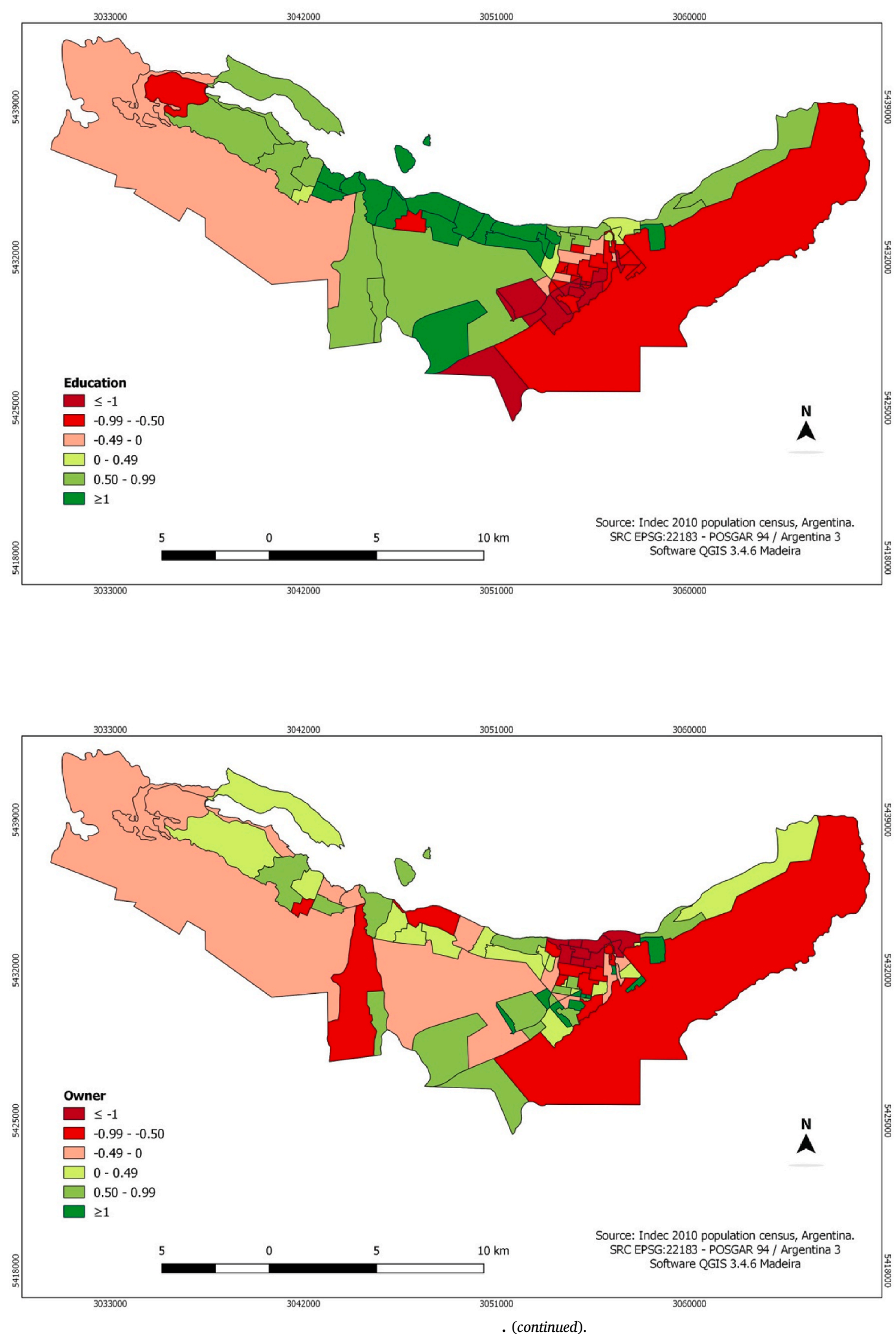

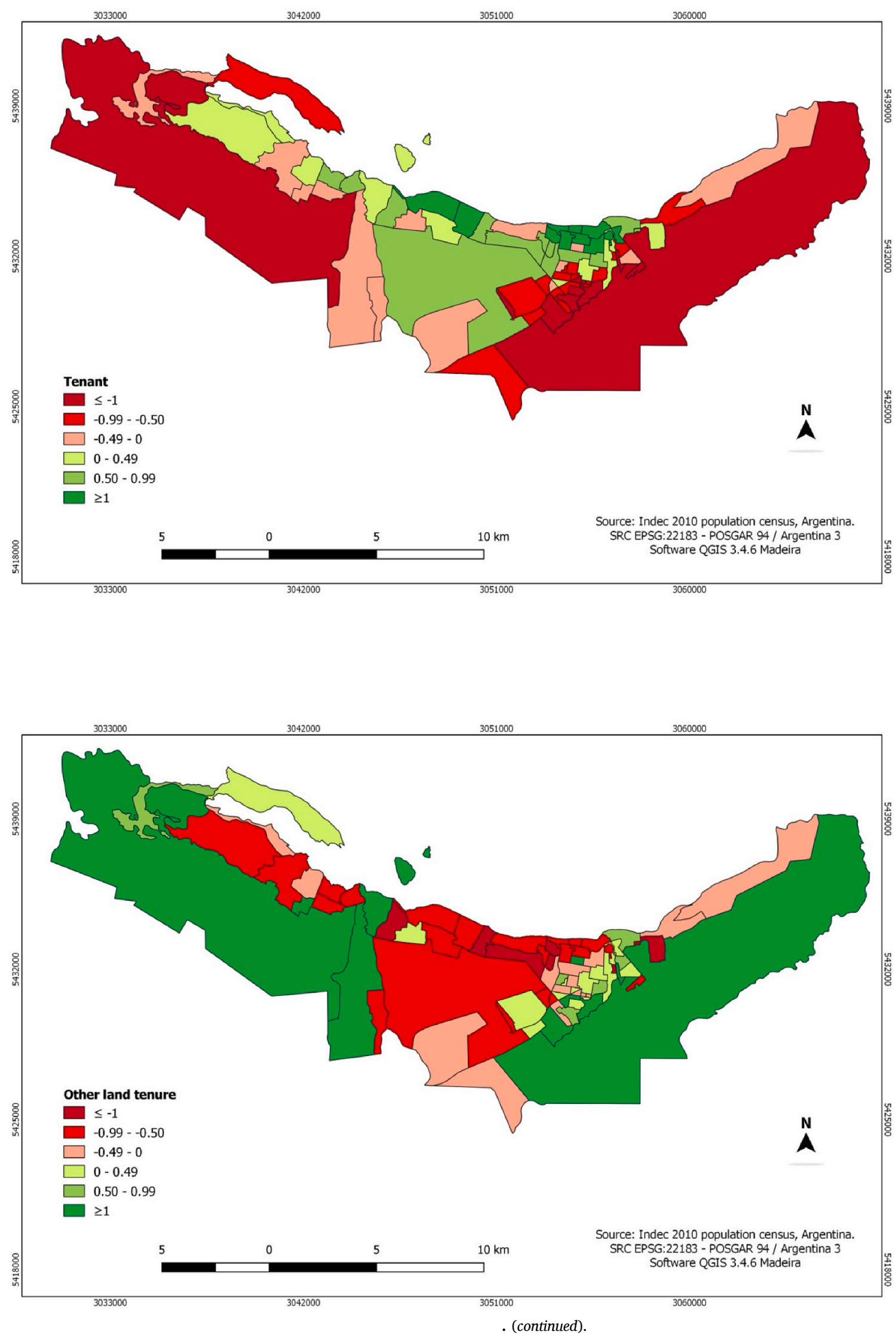
Appendix C. Neighborhoods (ID) by cluster

\begin{tabular}{|c|c|c|c|c|c|c|c|}
\hline \multirow{3}{*}{$\mathbf{A}$} & 34HAS & \multirow{8}{*}{ C } & $10 \mathrm{DIC}$ & \multirow{10}{*}{ F1 } & 3LAGOS_MORENO & \multirow{12}{*}{ G } & $112 \_84 \mathrm{~V}$ \\
\hline & NAH_MALV & & ABED_VURI & & CASAPIEDRA & & 154_204_218V \\
\hline & VIVERO & & ALBOR_BV & & CATEDRAL & & $181 \mathrm{~V}$ \\
\hline \multirow{5}{*}{ B1 } & $120 \mathrm{~V}$ & & CONDOR_NIRE_NE & & COIHUES & & $400 \_40 \mathrm{~V}$ \\
\hline & ARRAY_EVA & & LERA & & ESTE & & $96 \_144 \mathrm{~V}$ \\
\hline & CANTERA_OMEGA & & NVAESPER & & FALDEO_RANCHO & & ANTU170V \\
\hline & MUTI_PM & & QUINTAS_CEFE & & LLAO_CAMPAN & & ELFL 300V \\
\hline & PROGR ARG & & SANFRAN1 & & ORIONE VESCOND & & LEVA266V \\
\hline \multirow{6}{*}{ B2 } & COOP258 & \multirow{11}{*}{ D } & ANASAG & & SERENA JOCK & & PEUMA153V \\
\hline & FRUTI & & BELGRANO & & VICTORIAS & & QUIMEY \\
\hline & MONTEV_SUR & & CENTRO_NE & \multirow{11}{*}{ F2 } & $80 \mathrm{VCOVI}$ & & SANFRAN4_VIV \\
\hline & OMEGA & & CENTRO_NIRE_O & & BONITA_SIC & & SANMA169V \\
\hline & SANFRAN2_3 & & CENTRO_NO & & BOTANICO & \multirow{7}{*}{$\mathbf{H}$} & COLSUIZA \\
\hline & VIRGEN & & CENTRO_S & & KM4_5 & & CSOL_CHACRAS \\
\hline \multirow{3}{*}{ B3 } & LLANQUIH & & CENTRO_SO & & MAITEN_CIPRES & & GUTIER_ARELAU \\
\hline & PERIURB & & CUMBRE & & MARGARIT & & JAMAI_COVI \\
\hline & \multirow[t]{5}{*}{ PILAR } & & MALLIN_FURMAN & & MELIPAL & & OTTO_LADERAS \\
\hline & & & MICROCENTRO & & NMALAL & & PENINS \\
\hline & & & MONTEV_NORTE & & PAJAZUL & & TREBOL \\
\hline & & $\mathbf{E}$ & CAB_MILITAR & & PINARES & & \\
\hline & & & & & VERTIENT & & \\
\hline
\end{tabular}

Source: Own elaboration.

\section{Appendix D. Supplementary data}

Supplementary data to this article can be found online at https://doi.org/10.1016/j.habitatint.2020.102294.

\section{References}

Abaleron, C. A. (1995). Difusión espacial de la pobreza y destrucción del patrimonio natural: Las dos caras de una misma moneda. EURE - Journal of Latin American Urban and Regional Studies, 21(64), 61-74.

Abaleron, C. A. (2009). Diferencias y desigualdades socio-territoriales en la Patagonia Norte de Argentina. Revista LIDER, 15, 179-208.

Abaleron, C. A. (2016). Diferencias innatas y desigualdades socio-espaciales de calidad de vida en San Carlos de Bariloche, Argentina. Espacio, Tiempo Y Forma - Serie VI: Geografía, 8-9, 15-51.

Aguilar, A. G., \& Mateos, P. (2011). Diferenciación sociodemográfica del espacio urbano de la Ciudad de México. EURE - Journal of Latin American Urban and Regional Studies, 37(110), 5-30.

Aguirre, C., Blanco, C., Canals, C., Mena, C., Fábrega, F., \& Paulus, N. (2013). Elección escolar en contexto sociogeográficos diferenciados: Una tipología de comunas de la ciudad de Santiago. Working paper, Instituto de Filosofía y Ciencias de la Complejidad (IFICC), Santiago de Chile.

Baños Francia, J. A. (2012). Ocupación del territorio litoral en ciudades turísticas de México. Bitácora Urbano-Territorial, 20(1), 41-52.

Bingham, R. D., Bowen, W. M., \& Kimble, D. (1997). The Ohio edge cities Project. In R. D. Bingham, W. M. Bowen, \& Y. Amara (Eds.), Beyond edge cities. New York: Routledge.

Borsdorf, A., Hildalgo, R., \& Vidal-Koppmann, S. (2016). Social segregation and gated communities in Santiago de Chile and Buenos Aires. A comparison. Habitat International, 54, 18-27.

Brain, I., Cubillos, G., \& Sabatini, F. (2007). Integración social urbana en la nueva política habitacional. Dirección de Asuntos Públicos, 2(7), 1-15.

Brain, I., Prieto, J. J., \& Sabatini, F. (2010). Vivir en campamentos: ¿Camino hacia la vivienda formal o estrategia de localización para enfrentar la vulnerabilidad? EURE Journal of Latin American Urban and Regional Studies, 36(109), 111-141.

Burgos, S., Koifman, R. J., Montaño Espinoza, R., \& Atria Curi, J. (2011). Tipologías residenciales en comunidades chilenas en condiciones de precariedad habitacional. Revista Panamericana de Salud Públic, 29(1), 32-40.
Calderón, J. A. (1999). Algumas consideraciones sobre los mercados ilegales e informales de suelo urbano en América Latina. Lincoln Institute of Land Policy.

Castells, M. (1977). The urban question. London: Edward Arnold.

Celemín, J. P. (2012). Asociación espacial entre fragmentación socioeconómica y ambiental en la ciudad de Mar del Plata, Argentina. EURE - Journal of Latin American Urban and Regional Studies, 38(113), 33-51.

Celemín, J. P., \& Velázquez, G. (2017). Spatial analysis of the relationship between a life quality index, HDI and poverty in the province of buenos aires and the autonomous city of buenos aires, Argentina. Social Indicators Research, 140, 57-77.

Chow, J. (1998). Differentiating urban neighborhoods: A multivariate structural model analysis. Social Work Research, 22(3), 131-142.

de Córdova, G. F., Fernández-Maldonado, A. M., \& del Pozo, J. M. (2016). Recent changes in the patterns of socio-spatial segregation in Metropolitan Lima. Habitat International, 54, 28-39.

De Mattos, C. (2002). Transformación de las ciudades latinoamericanas: ¿ Impactos de la globalización? EURE - Journal of Latin American Urban and Regional Studies, 28(85), 5-10.

Dear, M. (2002). From Chicago to LA: Making sense of urban theory. London: Sage.

Delmelle, E. C. (2016). Mapping the DNA of urban neighborhoods: Clustering longitudinal sequences of neighborhood socioeconomic change. Annals of the Association of American Geographers, 106(1), 36-56.

Ellis, M., Wright, R., Holloway, S., \& Fiorio, L. (2018). Remaking white residential segregation: Metropolitan diversity and neighborhood change in the United States. Urban Geography, 39(4), 519-545.

Enríquez Acosta, J.Á. (2008). Las nuevas ciudades para el turismo: El caso de Puerto Peñasco, Sonora, México. Scripta Nova, 12(270), [electronic journal without pagination]. http://www.ub.edu/geocrit/-xcol/63.htm.

Everitt, J., Massam, B., Chávez-Dagostino, R., Espinosa Sánchez, R., \& Andrade Romo, E. (2008). The imprints of tourism on puerto vallarta, jalisco, Mexico. Canadian Geographer, 52(1), 83-104.

Ferguson, B., \& Navarrete, J. (2003). New approaches to progressive housing in Latin America: A key to habitat programs and policy. Habitat International, 27(2), 309-323. 
García-Ayllón, S. (2016). Rapid development as a factor of imbalance in urban growth of cities in Latin America: A perspective based on territorial indicators. Habitat International, 58, 127-142.

González-Pérez, J. M. (2013). Problemáticas urbanas en los enclaves turísticos: Turismo como estrategia para el ordenamiento urbano y territorial. Bitácora UrbanoTerritorial, 22(1), 138-140.

González-Pérez, J. M., Remond, R., Rullan, O., \& Vives, S. (2016). Urban growth and dual tourist city in the Caribbean. Urbanization in the hinterlands of the tourist destinations of Varadero (Cuba) and Bávaro-Punta Cana (Dominican Republic). Habitat International, 58, 59-74.

Griffin, E., \& Ford, L. (1980). A model of Latin American city structure. Geographical Review, 70(4), 397-422.

Hair, J., Black, W., Babin, B., \& Anderson, R. (2010). Multivariate data analysis. London: Pearson.

Hanlon, B. (2009). A typology of inner-ring suburbs: Class, race, and ethnicity in US suburbia. City \& Community, 8(3), 221-246.

Janoschka, M. (2002). El nuevo modelo de la ciudad latinoamericana: Fragmentación y privatización. EURE - Journal of Latin American Urban and Regional Studies, 28(85), 11-20.

Janoschka, M., \& Salinas Arreortua, L. (2017). Peripheral urbanisation in Mexico City. A comparative analysis of uneven social and material geographies in low-income housing estates. Habitat International, 70, 43-49.

Janoschka, M., \& Sequera, J. (2016). Gentrification in Latin America: Addressing the politics and geographies of displacement. Urban Geography, 37(8), 1175-1194.

Johnson, R., \& Wichern, D. (2008). Applied multivariate statistical analysis. London: Pearson.

Kaztman, R., \& Retamoso, A. (2005). Spatial segregation, employment and poverty. CEPAL Review, 85, 125-141.

Kaztman, R., \& Retamoso, A. (2007). Effects of urban segregation on education in Montevideo. CEPAL Review, 91, 133-153.

Kozulj, R. (2016). Aproximaciones a la identificación de la actividad económica de San Carlos de Bariloche 2014-2015. Working Paper, Universidad Nacional de Río Negro, Bariloche.

Krüger, N. (2019). La segregación por nivel socioeconómico como dimensión de la exclusión educativa: 15 años de evolución en américa latina. Archivos Analíticos de Políticas Educativas, 27(8), 1-33.

Link, F., Valenzuela, F., \& Fuentes, L. (2015). Segregación, estructura y composición social del territorio metropolitano en Santiago de Chile: Complejidades metodológicas en el análisis de la diferenciación social en el espacio. Revista de Geografía, Norte Grande, 62, 151-168.

Liu, Y., Fan, P., Yue, W., Huang, J., Li, D., \& Tian, Z. (2019). Assessing polycentric urban development in mountainous cities: The case of Chongqing Metropolitan Area, China. Sustainability, 11(10), 1-15.

López, Á., Cukier, J., \& Sánchez, Á. (2006). Segregation of tourist space in los cabos, Mexico. Tourism Geographies, 8(4), 359-379.

Manaugh, K., Miranda-Moreno, L. F., \& El-Geneidy, A. M. (2010). The effect of neighbourhood characteristics, accessibility, home-work location, and demographics on commuting distances. Transportation, 37(4), 627-646.

Marcos, M., Mera, G., \& Virgilio, M. M. (2015). Contextos urbanos de la Ciudad de Buenos aires: Una propuesta de clasificación de la ciudad según tipos de hábitat. Papeles de Población, 21(84), 161-196.

Marmolejo-Duarte, C., \& Batista-Dória de Souza, N. J. (2011). Estructura urbana y segregación socioresidencial: Un análisis para Maceió-Alagoas, Brasil. Papeles de Población, 17(70), 247-286.

Marmolejo-Duarte, C., Fitch-Osuna, J. M., \& Batista-Dória de Souza, N. J. (2012). Estructura urbana y segregación socioresidencial en América Latina. VIII Congreso Internacional Ciudad y Territorio Virtual, 1-38. Río de Janeiro.

Massey, D., \& Denton, N. (1993). American apartheid: Segregation and the making of the underclass. Cambridge, MA: Harvard University Press.

Mateos, P., \& Aguilar, A. G. (2013). Socioeconomic segregation in Latin American cities. A geodemographic application in Mexico City. Journal of Settlements and Spatial Planning, 4(1), 11-25.

Matossian, B. (2016). Urban fragmentation and neighborhood associations in San Carlos de Bariloche city, Patagonia-Argentina (1983-2015). Geographical Paper, 62, 1-4.

Medina, V. (2017). Las movilidades poblacionales y su impacto territorial en la estructura espacial de las ciudades turísticas: El caso de San Carlos de Bariloche. EURE - Journal of Latin American Urban and Regional Studies, 43(129), 71-92.

Mikelbank, B. A. (2004). A typology of US suburban places. Housing Policy Debate, 15(4), 935-964.

Mikelbank, B. A. (2011). Neighborhood déjà vu: Classification in metropolitan Cleveland, 1970-2000. Urban Geography, 32(3), 317-333.

Molinatti, F. (2013). Segregación residencial socioeconómica en la ciudad de Córdoba (Argentina): Tendencias y patrones espaciales. Revista INVI, 28(79), 61-94.

Murillo, J., Duk, C., \& Martínez Garrido, C. (2018). Evolución de la segregación socioeconómica de las escuelas de América Latina. Estudios Pedagogicos, 44(1), 157-179.

Niembro, A., Guevara, T., \& Cavanagh, E. (2019). Segregación residencial socioeconómica e inserción laboral: El caso de San Carlos de Bariloche, Argentina. Revista INVI, 34(97), 129-154.

Nun, J. (1969). Superpoblación relativa, ejército industrial de reserva y masa marginal. Revista Latinoamericana de Sociología, 5(2), 180-225.

Owens, A. (2012). Neighborhoods on the rise: A typology of neighborhoods experiencing socioeconomic ascent. City \& Community, 11(4), 345-369.

Pallas-González, J., Martínez-Roget, F., \& Miranda-Torrado, F. (2000). Clasificación multivariante: Una aplicación a las comarcas gallegas. Anales de Economía aplicada. XIV reunión ASEPELT-españa, oviedo.
Park, R. E., Burgess, E. W., \& McKenzie, R. D. (1925). The city. Chicago: University of Chicago Press.

Patel, A., Koizumi, N., \& Crooks, A. (2014). Measuring slum severity in Mumbai and Kolkata: A household-based approach. Habitat International, 41, 300-306.

Patel, A., Shah, P., \& Beauregard, B. (2020). Measuring multiple housing deprivations in urban India using Slum Severity Index. Habitat International, 101, 1-13.

Pérez, S. A. (2004). Identidades urbanas y relocalización de la pobreza. Intersecciones en Antropología, 5, 177-186.

Quijano, A. (1972). La constitución del "mundo" de la marginalidad urbana. EURE Journal of Latin American Urban and Regional Studies, 2(5), 89-106.

Reibel, M., \& Regelson, M. (2007). Quantifying neighborhood racial and ethnic transition clusters in multiethnic cities. Urban Geography, 28(4), 361-376.

Roberts, B. R., \& Wilson, R. H. (2009). Urban segregation and governance in the Americas. New York: Palgrave Macmillan.

Rodríguez, J. (2001). Segregación residencial socioeconómica: Qué es?, cómo se mide?, qué está pasando?, importa?. Serie población y desarrollo No. 16. Santiago, Chile: United Nations.

Rodríguez, J., \& Arriagada, C. (2004). Segregación residencial en la ciudad latinoamericana. EURE - Journal of Latin American Urban and Regional Studies, 29 (89), 5-24.

Rodríguez, A., Riofrío, G., \& Welsh, E. (1973). Segregación residencial y desmovilización política: El caso de Lima. Buenos Aires: Ediciones SIAP.

Roy, D., Bernal, D., \& Lees, M. (2020). An exploratory factor analysis model for slum severity index in Mexico City. Urban Studies, 57(4), 789-805.

Ruiz-Rivera, N., \& van Lindert, P. (2016). Urban segregation in Latin America. Habitat International, 54, 1-2.

Sabatini, F., Cáceres, G., \& Cerda, J. (2001). Segregación residencial en las principales ciudades chilenas: Tendencias de las tres últimas décadas y posibles cursos de acción. EURE - Journal of Latin American Urban and Regional Studies, 27(82), 21-42.

Salom, J., \& Fajardo, F. (2017). Cambios recientes en la estructura territorial sociodemográfica del área metropolitana de Valencia (2001-2011). Boletín de la Asociación de Geógrafos Españoles, 73, 123-147.

Sampson, R. J., Morenoff, J. D., \& Gannon-Rowley, T. (2002). Assessing "neighborhood effects": Social processes and new directions in research. Annual Review of Sociology, 28(1), 443-478.

Sánchez Molina, R. (2002). Homo infantilis: Asimilación y segregación en la política colonial española en Guinea ecuatorial. Disparidades - Revista de Antropología, 57(2), 105-120.

Sánchez, D., Sassone, S., \& Matossian, B. (2007). Barrios y áreas sociales de San Carlos de Bariloche: Análisis geográfico de una ciudad fragmentada. IX Jornadas Argentinas de Estudios de Población, 1-18.

Scarpaci, J. L., Infante, R. P., \& Caete, A. (1988). Planning residential segregation: The case of Santiago, Chile. Urban Geography, 9(1), 19-36.

Sharkey, P., \& Faber, J. W. (2014). Where, when, why, and for whom do residential contexts matter? Moving away from the dichotomous understanding of neighborhood effects. Annual Review of Sociology, 40, 559-579.

Silveira, M., \& Rodrigues, A. (2015). Touristic urbanization in Brazil: A focus on florianópolis-Santa Catarina. Via@ Tourism Review, 1(7), 1-13.

Smets, P., \& Salman, T. (2016). The multi-layered-ness of urban segregation: On the simultaneous inclusion and exclusion in Latin American cities. Habitat International, $54,80-87$.

Soja, E. W. (2000). Postmetropolis: Critical studies of cities and regions. Malden: Blackwell Publishers.

Song, Y., \& Knaap, G.-J. (2007). Quantitative classification of neighbourhoods: The neighbourhoods of new single-family homes in the Portland Metropolitan Area. Journal of Urban Design, 12(1), 1-24.

Telles, E. E. (1995). Structural sources of socioeconomic segregation in Brazilian metropolitan areas. American Journal of Sociology, 100(5), 1199-1223.

Torres, R. M., \& Momsen, J. D. (2005). Gringolandia: The construction of a new tourist space in Mexico. Annals of the Association of American Geographers, 95(2), 314-335.

Valenzuela Valdivieso, E., \& Coll-Hurtado, A. (2010). In La construcción y evolución del espacio turístico de Acapulco (México). Anales de Geografía de la Universidad Complutense (Vol. 30, pp. 163-190).

Vásquez, E. M., Peña, I., \& Cardona, Á. M. S. (2008). Clasificación de los hogares según su perfil de salud, para la focalización de recursos destinados a prevención, promoción y recuperación, Medellín, 2004. Revista de la Facultad Nacional de Salud Pública, 26 (1), 56-68.

Vejsbjerg, L., Núñez, P., \& Matossian, B. (2014). Transformation of frontier national Parks into tourism sites. The north andean Patagonia experience (1934-1955). Almatourism - Journal of Tourism, Culture and Territorial Development, 5(10), 1-22.

Velázquez, G. (Ed.). (2016). Geografía y calidad de vida en Argentina. Análisis regional y departamental (2010). Tandil. Argentina: Universidad Nacional del Centro de la Provincia de Buenos Aires.

Velázquez, G., \& Celemín, J. P. (2019). Geografía y calidad de vida en la Argentina: Análisis según departamentos y radios censales (2010). Journal de Ciencias Sociales, 7 (13), 88-113.

Velázquez, G., \& Celemín, J. P. (2020). Calidad de vida y escala urbana según regiones en la República Argentina (2010). Anales de Geografía de la Universidad Complutense, 40 (1), 251-272.

Vicino, T. J., Hanlon, B., \& Short, J. R. (2011). A typology of urban immigrant neighborhoods. Urban Geography, 32(3), 383-405.

Virgilio, Di, M, M., Marcos, M., \& Mera, G. (2016). Heterogeneidades sociohabitacionales en la ciudad de Buenos aires: Indagaciones sobre la base de una tipología de entornos urbanos. Cuaderno Urbano, 20(20), 163-189. 
Wacquant, L. J. (1993). Urban outcasts: Stigma and division in the black American ghetto and the French urban periphery. International Journal of Urban and Regional Research, 17(3), 366-383.

Webber, R. J., \& Craig, J. A. (1978). Socio-economic classification of local authority areas. Studies on Medical and Population Subjects No., 35.

Weeks, J., Hill, A., Stow, D., Getis, A., \& Fugate, D. (2007). Can we spot a neighborhood from the air? Defining neighborhood structure in accra, Ghana. Geojournal, 69(1), $9-22$.

Wei, F., \& Knox, P. L. (2014). Neighborhood change in metropolitan America, 1990 to 2010. Urban Affairs Review, 50(4), 459-489.

Wilde, G. (1999). ¿Segregación o asimilación? La política Indiana en américa Meridional a fines del período colonial. Revista de Indias, 59(217), 619-644.
Wirth, L. (1938). Urbanism as a way of life. American Journal of Sociology, 44(1), 1-24. Wu, F., He, S., \& Webster, C. (2010). Path dependency and the neighbourhood effect: Urban poverty in impoverished neighbourhoods in Chinese cities. Environment \& Planning A, 42(1), 134-152.

Yao, J., Wong, W., Bailey, N., \& Minton, J. (2018). Spatial segregation measures: A methodological review. Tijdschrift voor Economische en Sociale Geografie, 110(3), 235-250.

Zhou, D., Xu, J., Radke, J., \& Mu, L. (2004). A spatial cluster method supported by GIS for urban-suburban-rural classification. Chinese Geographical Science, 14(4),

337-342. 